\title{
Questions and Answers on the Belgian Model of Integral End-of-Life Care: Experiment? Prototype?
}

\author{
"Eu-Euthanasia": The Close Historical, and Evidently Synergistic, Relationship \\ Between Palliative Care and Euthanasia in Belgium: An Interview With a Doctor \\ Involved in the Early Development of Both and Two of His Successors
}

\author{
Jan L. Bernheim • Wim Distelmans • Arsène Mullie • \\ Michael A. Ashby
}

Received: 16 June 2013 / Accepted: 10 April 2014 / Published online: 16 August 2014

(C) Springer Science+Business Media Dordrecht 2014

\begin{abstract}
This article analyses domestic and foreign reactions to a 2008 report in the British Medical Journal on the complementary and, as argued, synergistic relationship between palliative care and euthanasia in Belgium. The earliest initiators of palliative care in Belgium in the late 1970s held the view that access to proper
\end{abstract}

This paper has been rewritten as an interview with MA, based on an original draft received by him from the three Belgian authors (JB, $\mathrm{WD}, \mathrm{AM}$ ) for informal advice about publication. The opinions expressed in this article are the latters' own and do not necessarily reflect the views of their organisations or employers. Answers were drafted by JB and complemented or corrected by WD and AM, who agreed with the final version. Where the positions of the authors or the FPCFl and LEIF organisations differ, these divergences are reflected in the text. WD sees some differences as fundamental.

J. L. Bernheim $(\bowtie)$

End-of-Life Care Research Group, Vrije Universiteit Brussel and Ghent University, Faculty of Medicine and Pharmacy, Vrije Universiteit Brussel, Laarbeeklaan, 103, 1090 Brussels, Belgium

e-mail: jan.bernheim@vub.ac.be

W. Distelmans

Supportive and Palliative Care Department, UZ Brussel, Brussel, Belgium

A. Mullie

Federation Palliative Care Flanders, Vilvoorde, Belgium

M. A. Ashby

Royal Hobart Hospital, Southern Tasmania Health

Organisation, and School of Medicine, Faculty of Health

Sciences, University of Tasmania, Tasmania, Australia palliative care was a precondition for euthanasia to be acceptable and that euthanasia and palliative care could, and should, develop together. Advocates of euthanasia including author Jan Bernheim, independent from but together with British expatriates, were among the founders of what was probably the first palliative care service in Europe outside of the United Kingdom. In what has become known as the Belgian model of integral end-oflife care, euthanasia is an available option, also at the end of a palliative care pathway. This approach became the majority view among the wider Belgian public, palliative care workers, other health professionals, and legislators. The legal regulation of euthanasia in 2002 was preceded and followed by a considerable expansion of palliative care services. It is argued that this synergistic development was made possible by public confidence in the health care system and widespread progressive social attitudes that gave rise to a high level of community support for both palliative care and euthanasia. The Belgian model of so-called integral end-oflife care is continuing to evolve, with constant scrutiny of practice and improvements to procedures. It still exhibits several imperfections, for which some solutions are being developed. This article analyses this model by way of answers to a series of questions posed by Journal of Bioethical Inquiry consulting editor Michael Ashby to the Belgian authors.

Keywords Palliative care $\cdot$ Euthanasia $\cdot$ Death and dying $\cdot$ Belgium 


\section{Introduction}

An original study (Bernheim et al. 2008), which was more recently updated (Bernheim et al. 2012), presented historical, regulatory, and epidemiological data showing that in Belgium the promotion of the legalisation of euthanasia and the advocacy of the development of palliative care (PC) were synergistic, rather than antagonistic. It has also been demonstrated that since the legalisation of euthanasia, PC has strongly expanded and prudence in decision-making and care at the end of life has improved. No substantial evidence of socalled practical "slippery slope" (van der Burg 1991) phenomena has been found (Bernheim et al. 2008; Bernheim et al. 2012; Chambaere et al. 2010a; Lewis and Black 2013 ${ }^{1}$ ), and Belgians' confidence in their health care system, already high before the euthanasia legislation, further rose to the second-highest in Europe (European Values Study 2008).

Since 2008 several papers have vigorously challenged this "synergy" article, with two main types of criticism. Some took issue with the data and pragmatic considerations, arguing that the legal safeguards against abuse are insufficiently enforced (Materstvedt 2009; Pereira 2011; Cohen-Almagor 2013), and others aimed to refute the conclusions on fundamental ideological grounds (Jaspers, Müller-Busch, and Nauck 2009; Kettler and Nauck 2010; Johnstone 2012; Materstvedt 2012). The "synergy" paper proposed the concept of "integral palliative care" to denote the Federation of Palliative Care Flanders' (FPCFl) endorsement and integration of euthanasia. To date, worldwide, this is the only professional PC organisation to have done so (Federatie Palliatieve Zorg Vlaanderen 2003; Vanden Berghe et al. 2013). We have also argued that some individual patients' requests for euthanasia stem from their judgement that the initiation or pursuit of palliative care is "futile." This is because PC

\footnotetext{
${ }^{1}$ The Lewis and Black (2013) article exhaustively reviews all extant data in "permissive" countries on reported cases of granted and refused assisted dying. Their aim is to investigate the degree of compliance with legal requirements for the validity of requests of assisted dying. They conclude that the "evidence from the four jurisdictions reviewed (the Netherlands, Belgium, Oregon and Switzerland) suggests that the legal criteria that apply to an individual's request for assisted dying are well respected" (Lewis and Black 2013, 895). "Well" is the key qualification. The very same imperfections that Lewis and Black detect are enlarged and misinterpreted by Pereira (2008) and Cohen-Almagor (2013) to represent ominous slippery slope effects. Pereira's allegations were refuted or discredited (Downie, Chambaere, and Bernheim 2013).
}

does not or no longer meets the needs and wishes of those patients who prefer to have assistance to die rather than a protracted "natural" death in a palliative care program (however well-intentioned and however good the support and symptom control). Both concepts of "integral" and "futile" palliative care have been ideologically challenged in the last few years (Jaspers, Müller-Busch, and Nauck 2009; Kettler and Nauck 2010; Johnstone 2012; Materstvedt 2012). A response to these theoretical objections is in preparation.

After presentations of the "synergy" data, there also were many questions asked and objections raised, mainly internationally. These questions include the following:

1. What is it like for a doctor to perform euthanasia?

2. What is the influence of a medical practitioner's personal beliefs and views on his or her willingness to participate in euthanasia?

3. How did the Belgian model of end-of-life care come about?

4. Why is there 20 times more euthanasia than physician-assisted suicide?

5. How is the Belgian model organised? What is "integral palliative care"? What else is "integral end-oflife care"?

6. Does the Belgian model have international relevance?

7. Why did synergy between palliative care and euthanasia first emerge in Belgium?

8. What are the Belgian model's failings?

9. How might the Belgian model evolve?

This article responds to these questions and concerns. For linguistic and stylistic reasons, it was felt that this information and experience could best be conveyed by an interview format, between Michael Ashby (MA), consulting editor of the Journal of Bioethical Inquiry and a former resident of Belgium, and the authors (JB, WD, AM).

\section{Question One: What Is It Like for a Doctor to Perform Euthanasia?}

MA: Clinicians in jurisdictions where euthanasia remains illegal have a wide range of reactions, from envy to outrage. Many wonder what it feels like to carry out euthanasia. 
The overall thrust of our response is that careful euthanasia is simply the continuation of our medical practice and that we find satisfaction in respecting the explicit and well-considered wish of the patient, which in Belgium is possible in full conformity with the law. The law provides a reassuring procedural framework that helps with observing the ethical requirements to respect patient autonomy, to act beneficently, and to do no harm (Deliens and van der Wal 2003; De Keyser 2003). We also endeavour to show a high level of respect for the person concerned, for the importance of his or her life and significance of his or her death, and for his or her choice of the time and manner of dying. All three of us have experienced that euthanasia is almost always followed by a serene bereavement of those close to the patient, more notable than after conventional deaths. This is in line with Dutch epidemiological data (Swarte et al. 2003). The family's appreciation is usually manifest, even when, as is often the case, they have had prior reservations about euthanasia. This experience is confirmed by a Dutch qualitative study of the psychological and philosophical aspects of euthanasia requests (Kimsma 2010). In short, the professional rewards are similar to those experienced when suffering is relieved and peace-in-death is achieved with conventional palliative care. Another satisfaction, and one we share with many Benelux oncologists, is the (admittedly so far statistically unproven) impression that patients who are assured euthanasia if and when they judge the time has come tend to live longer than their counterparts dying conventionally. This need not be paradoxical for several reasons. First, euthanasia anyway has an only modest impact on lifespan: The estimated hastening of death in 55.5 percent of patients who die by euthanasia is less than one week (Chambaere et al. 2010a). Second, the perspective of a good death seems to confer psychological advantages such as reduced anxiety, more attention to spiritual accomplishment, and more concentration on quality of life, all of which may promote a hanging onto life. Third, treatment acceptance and compliance may be increased. For example, some patients agree to lifeprolonging treatment only on condition that, if nontolerated adverse effects occur, they will be granted euthanasia. One of author JB's patients testified to this in a documentary: She accepted whole-brain irradiation for multiple cancer metastases only on that condition and lived for almost another year (Van de Velde 2012). ${ }^{2}$

For author WD, euthanasia is above all a choice by a competent and well-informed patient (and not a decision by the physician), so that all the doctor has to do is decide for himself or herself whether to participate - that is, to be instrumentally and actively involved in the process of euthanasia. For WD, euthanasia is emotionally no different from other life-abbreviating decisions such as the discontinuation of life-prolonging treatment. The process before euthanasia is intensive (informative and deliberative), and the performing of euthanasia is a final professional act. Authors AM and JB share this view, but also experience additional feelings. AM adheres to a Christian spiritualist tradition. For him, to help a patient die is deeply moving and has a life-intensifying and sacred dimension. JB, an atheist, feels drained after euthanasia, but relieved, and satisfied to have served autonomy and quality of life, which in the framework of his progressive evolutionary worldview (Bernheim 1999a; Heylighen and Bernheim 2000a, b) has a transcendental meaningfulness. For him, euthanasia feels much like delivering a baby.

\section{Question Two: What Is the Influence of a Medical Practitioner's Personal Beliefs and Views on His or Her Willingness to Participate in Euthanasia?}

\begin{abstract}
MA: In the "Rapid Response" e-section of the British Medical Journal following your 2008 paper, some commentators argued that apparently pragmatic objections against euthanasia such as slippery slope concerns are, in fact, smokescreens that obscure fundamentally religious objections to euthanasia. In your experience, do personal worldview, values, and beliefs determine physicians' attitudes towards euthanasia and its practice?
\end{abstract}

\footnotetext{
$\overline{2}$ The hypothesis that, like palliative care (Temel et al. 2010), euthanasia may be associated with longer survival than conventional death can easily be put to a first test by - on condition that immediate cause of death is registered-comparing the respective survival durations of advanced cancer patients from the Benelux countries who participate in the multi-centric trials of the European Organisation for Research and Treatment of Cancer (EORTC), up to 10 percent of whom die with euthanasia (Van der Heide et al. 2007; Chambaere et al. 2010a).
} 
This debate can be informed by empirical data. As in the United Kingdom (Seale 2010) and other countries (Bülow et al. 2012), in Belgium practicing religious palliative care physicians are more critical of euthanasia than others (Broeckaert et al. 2009). Perhaps surprisingly, in a survey of British students there was a significant positive correlation between religious belief and a positive attitude towards euthanasia, a finding suggesting a cultural shift to Hains and Hulbert-Williams (2013). Europe-wide comparative research shows that personal worldview does have some influence, but that the national cultural and legal context counts for much more. In countries where euthanasia is legal ("permissive" countries), religious physicians are much more favourable towards euthanasia than in countries where it is not, and non-believers in the latter countries tend to report higher levels of opposition (Miccinesi et al. 2005; Cohen et al. 2008). It appears, therefore, that the surrounding culture strongly influences personal views, and perhaps euthanasia legislation changes the culture. In permissive countries the main determinants of physicians' willingness to perform euthanasia are not physician- but patient-related: The clinical condition of the patients and their wishes are foremost. The predominance of patient interests over physician views is of itself an important ethical stance (Hunt 1994).

The relationship between euthanasia and spiritual or existential caregiving to the patient has been examined in a study involving the last three months of life of patients of a representative panel of Belgian general practitioners (Van den Block et al. 2009). When euthanasia was performed, there was clear evidence of exceptionally high levels of spiritual or existential care. Religious or existential care is therefore not excluded at all from the care of people who request euthanasia but, rather, connected to it. Since in Belgium, which predominantly has a Catholic tradition, this type of care is more often religious than secular, we can infer that religious beliefs often do not, as a matter of course, restrain many patients from presenting requests for euthanasia. A new development is what we term "solemn or ceremonial" euthanasia, carried out at a predetermined time and place, among family loved ones and sometimes also in the presence of a pastor who has administered the last rites. For example, a recent documentary followed a cancer patient over the last six months of her life in palliative care and ends with her euthanasia in the supportive company of her family and friends that takes place in her home and is carried out by her general practitioner (GP) and palliative care nurse (Lanssens 2011). Another documentary showed a 90- year-old woman with refractory cancer symptoms preparing to undergo euthanasia and her interactions prior to doing so with Dr. Marc Desmet, a respected Belgian palliative care physician who is also a Jesuit priest (Gilsenan 2012). Applying Anamnestic Comparative Self Assessment (ACSA), a method to let respondents construct a personal scale of subjective well-being (Bernheim 1999b; Theuns, Hofmans; and Bernheim 2014), as an instrument of spiritual care, Desmet asks his patient what was the happiest time in her life. "Assisting my parents to die at home," she replies. Patient and doctor communicate warmly. When Dr. Desmet is asked by the interviewer Alan Gilsenan whether his religious beliefs are not an obstacle to granting euthanasia, the physician points out that according to Christian tradition one's conscience and compassion trump doctrine. He will entrust the patient to a colleague rather than performing the euthanasia himself, but he will accompany his patients "as far as he can go." Dr. Desmet had previously debated author JB and written a book opposing euthanasia (Desmet 2000). He now heads the ethics group of the Flemish Association for Palliative Care (Vanden Berghe et al. 2013).

\section{Question Three: How Did the Belgian Model of End-of-Life Care Come About?}

MA: In view of the fact that worldwide, except in Belgium and possibly the Netherlands (Leget 2013), the official stance of mainstream palliative care vis à vis euthanasia is rejection or at best "studied neutrality" (Johnstone 2012; Canadian Hospice Palliative Care Association 2010), why was this otherwise in Belgium? Why did the Federation Palliative Care Flanders depart from the tenet of palliative care "to neither prolong nor shorten life," as stated in the WHO (2014) definition of palliative care? Why were the first palliative care initiatives taken by proponents of legal euthanasia, and what motivated some pioneers of PC to adopt what they labelled "integral palliative care" (PC including legal euthanasia)?

In the United Kingdom, palliative care was introduced with one of its stated aims being to prevent euthanasia (Saunders 1976). This was not at all so in Belgium: An initial major motive for the introduction of 
palliative care was also to promote the acceptability of euthanasia (Bernheim 1990, 1996; Distelmans 2010). The Belgian founders of palliative care, authors JB and WD and others, deemed euthanasia unethical if it was conducted for lack of adequate palliative care services but supported euthanasia as a means for offering patients real choices. Many, including author AM, rallied to this position. A number of later PC workers tended to be proponents of palliative care only, who opposed euthanasia (e.g., Zuster Léontine 1995; Desmet 2000; Gamester and Van den Eynden 2009), and single-issue euthanasia campaigners also emerged across the community. The latter were not opposed to palliative care but only to "futile palliative doggedness." They felt that a prolonged dying with palliative care was unacceptable to those suffering individuals who preferred a rapid, self-willed death (Van den Enden 1995).

Upon closer examination, the foundational ethical principles invoked by the two opposing groups of activists were and remain largely similar. These shared values are best encapsulated by the notion of the centrality of the patient and compassion, with due regard for the classic medical ethics values of autonomy, beneficence, nonmaleficence, and justice (Hurst and Mauron 2006; Woods 2007). For euthanasia there is, however, an emphasis on patient autonomy, and for palliative care the emphasis is on exemplary care for the patient. The conventional palliative care movement opposes medical futility and so does the euthanasia movement (Bernheim, Vansweevelt, and Annemans 2014), which in addition opposes palliative futility, the continuance of palliative care against the wishes of the patient (see Table 1).

The common ground between those who sought better palliative care and those who were campaigning for the legalisation of euthanasia, together with the influence of the core group of those who supported both, gradually created a climate of public and professional opinion that was open to the possibility of euthanasia legislation.

The federal political system in Belgium is complex. It has to accommodate the two major language groups (Dutch-Flanders and French-Wallonie), a bilingual capital (Brussels), and a small German-speaking

Table 1 Foundations of palliative care and of legal euthanasia: Many similarities and a few differences

\begin{tabular}{|c|c|c|}
\hline & Palliative Care & Legal Euthanasia \\
\hline $\begin{array}{l}\text { Fundamental paradigm } \\
\text { Attributes of caregivers }\end{array}$ & $\begin{array}{l}\text { Centrality of the patient } \\
\text { Competence and compassion }^{\mathrm{a}}\end{array}$ & $\begin{array}{l}\text { Centrality of the patient } \\
\text { Competence and compassion }^{\mathrm{a}}\end{array}$ \\
\hline Clinical objectives & $\begin{array}{l}\text { 1. Relief of suffering } \\
\text { 2. Prevention of medical futility }\end{array}$ & $\begin{array}{l}\text { 1 Relief of suffering } \\
\text { 2. Prevention of palliative futility }\end{array}$ \\
\hline $\begin{array}{l}\text { Perception of most prominent } \\
\text { ethical values }\end{array}$ & $\begin{array}{l}\text { 1. Beneficence } \\
\text { 2. Patient autonomy }\end{array}$ & $\begin{array}{l}\text { 1. Patient autonomy } \\
\text { 2. Beneficence } \\
\text { b }\end{array}$ \\
\hline Life stance of activists & Often religious & Often agnostic or atheistic \\
\hline Potential for abuse ${ }^{c}$ & $\begin{array}{l}\text { 1 Palliative futility } \\
\text { 2. Under the pretence of observing the PC tenet } \\
\text { of not prolonging life (WHO), denying } \\
\text { life-prolonging treatment to a patient who } \\
\text { is doing well in PC. }\end{array}$ & $\begin{array}{l}\text { 1. Slippery slope phenomena } \\
\text { 2. Substitute for palliative care } \\
\text { 3. Erosion of public confidence in the } \\
\text { health care system }\end{array}$ \\
\hline Public support & $\begin{array}{l}\text { Well-nigh universal } \\
\text { Distrust by some professionals and politicians }{ }^{\mathrm{d}}\end{array}$ & $\begin{array}{l}\text { Large and growing majority in the } \\
\text { advanced countries. } \\
\text { Distrust by some professionals and } \\
\text { politicians }\end{array}$ \\
\hline
\end{tabular}

\footnotetext{
a See, e.g., de Zulueta 2013

${ }^{\mathrm{b}}$ In this order, though the common virtue overarching both beneficence and respect for autonomy is compassion, i.e. the capacity and propensity to put oneself in another person's place)

${ }^{\mathrm{c}}$ it should be emphasised here that the reality of medical futility (Bernheim, Vansweevelt, and Annemans 2014) probably dwarfs any abuses of palliative care, that, as detailed below, abuses of euthanasia did not materialise, and that any imperfections in the application of the euthanasia law only minimally detract from the major improvements in the carefulness of end-of-life practices relative to the situation before the law (Deliens et al 2000; Chambaere et al. 2011b)

${ }^{\mathrm{d}}$ Some still discern many opponents of euthanasia in the PC movement and suspect them to only pay lip service to the Flemish PC's official doctrine of comprehensive PC

${ }^{\mathrm{e}}$ The advocacy of further liberalisation of euthanasia elicits new oppositions
} 


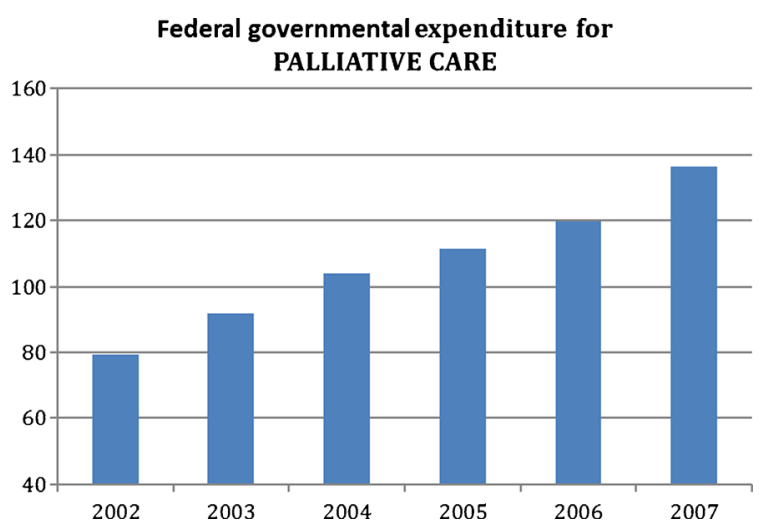

Fig. 1 Federal governmental expenditure for palliative care services in Belgium (in million Euros $[€]$ per year) since the legalisation of euthanasia in 2002 (see the Federal Evaluation Cell on Palliative Care 2008)

community in the east of the country. In effect, Belgium is multilingual and multicultural, arguably prefiguring e.g. the European Union and things to come elsewhere in a globalising world.. Political parties and institutions of all persuasions are divided between the two largest language groups. The country is used to coalition government, compromise, and so-called "waffle-iron" politics (the habit of when one constituency has scored, compensating the other) (Perrez and Reuchamps 2012). The composition of the Belgian parliament gave rise to a unique opportunity in 2002 when a governing left-ofcentre coalition of liberals, social democrats and greens left the Christian democrats out of the governing coalition for the first time in five decades (Griffiths, Weyers and Adams 2008). In lengthy negotiations, the "confessionals" (essentially the Christian democrats) secured "their" development of palliative care and the secular "free-thinkers" "their" legalisation of euthanasia, while both constituencies sponsored the Patient Rights Bill. The joint three laws on euthanasia, palliative care and patient rights were in fact the "waffle-iron"-like political implementation of a lengthy deliberative process. However, the left-of-centre political coalition valued palliative care no less than the religiously inspired minority. Subsequently, during the five years following the twin laws on euthanasia and palliative care, yearly federal expenditure for palliative care increased from $€ 78$ million to $€ 137$ million (Federal Evaluation Cell on Palliative Care 2008; see Fig. 1). The palliative care budget has continued to rise annually by 10 percent, and Belgian palliative care, according to European Association for Palliative Care (EAPC) indicators (Chambaere et al. 2011a), is on a par with the reference United Kingdom (Bernheim et al. 2014).

At the micro-level of organisations and individual caregivers, motives were both multiple and complex. Many proponents of legal euthanasia valued palliative care per se, but also considered the unavailability of palliative care to be an unwanted indication for euthanasia and a legitimate objection against its legalisation. It is with this double motivation that they became pioneers of palliative care (Bernheim 1990, 1996; Distelmans 2010).

The motivation of diverse palliative caregivers, including religious ones, to embrace euthanasia was also dual. While they adhered to the principle of the primacy of the patient's values, they also entertained the practical hope that by embedding euthanasia in palliative care they would set standards for quality of care and contribute to the prevention of slippery slope effects (Bernheim et al. 2008; Federatie Palliatieve Zorg Vlaanderen 2013;

Table 2 Activists' motivations for synergy between legal euthanasia and development of palliative care

Motivations

Of Activists for LEGAL EUTHANASIA to Promote PALLIATIVE CARE

ETHICAL

PRAGMATIC

MACRO LEVEL

(Political decision-making)

MICRO LEVEL

(Individual decision-making)

- Intrinsic value of PC

- Prevention of euthanasia for lack of PC services
Political reciprocity

- Intrinsic value of PC

- Prevention of euthanasia for lack of PC services
Of Activists for PALLIATIVE CARE to Promote LEGAL EUTHANASIA

- Centrality of patient autonomy

Political reciprocity

- Centrality of patient autonomy

- Regulating clandestine practices

- Ambition of exemplary role for "eu-euthanasia" 
Vanden Berghe et al. 2013). The amendment desired by the Palliative Care Federation of Flanders (FPCFl) to make a "palliative filter" legally required (palliative care physicians as gatekeepers for euthanasia) was not accepted by the political majority because too many palliative care specialists were on record as being opposed to euthanasia and it was considered that such a hurdle would be too taxing and stressful for the patient. The palliative care federations have made their peace with not being made the gatekeepers for euthanasia, all the more because they have no wish to take the place of other clinicians but, rather, explicitly work to empower them for end-of-life care (Vanden Berghe et al. 2013). Thus, what palliative care physicians hoped for by taking euthanasia on board was to function as an example: They saw in their palliative care doctrine of "total" care a standard of care also for euthanasia. If euthanasia was to be legal, it had to be with the best possible care, "eueuthanasia," as it were. Just as — etymologically_-"euthanasia" means "good death," so "eu-euthanasia" denotes "giving the good death well" (see Table 2).

In short, in Belgium euthanasia and palliative care have developed in a connected, interdependent, and reciprocal way: The motives of advocates to promote both palliative care and legal euthanasia were intrinsic (intellectual) as well as extrinsic (pragmatic). This is largely because palliative care and euthanasia are based on closely related ethics of care (Hurst and Mauron 2006; Woods 2007; see Table 2). Moreover, we submit that the overarching motivation of all caregivers is compassion, the capacity and propensity to put oneself in another person's place, and compassion, so understood, also includes respect for autonomy.

\section{Question Four: Why Is There 20 Times More Euthanasia Than Physician-Assisted Suicide?}

MA: About 2 percent of Belgians (and Dutch) die with euthanasia, where the physician administers the lethal drugs, and less than 0.1 percent by physician-assisted suicide, where the patient ingests the drug provided by the physician (Bilsen et al. 2009). The latter modest proportion is similar to Oregon's, where only physicianassisted suicide is legal (Oregon Public Health Division 2013). Why is physician-assisted suicide only marginal in the Benelux countries?
We don't precisely know because the question has not yet been systematically studied. Many physicians state that they ideally prefer to offer the means for suicide rather than to carry out euthanasia, because the autonomy of the patient is thus more in evidence. However, though 34 percent of Dutch general practitioners prefer assisted suicide, only 22 percent offer the two options to the patients requesting assisted dying (Kouwenhoven et al. 2014). There is anecdotal evidence that, when given the choice, many more patients opt for euthanasia than for assisted suicide. This may be because they have more trust in the physician doing it right than in themselves. Physicians may share this feeling, for example, worrying about malabsorption of the barbiturate potion (Groenewoud et al. 2000). However, other psychological factors seem to play a part. Perhaps the preference of some patients to be passive is underestimated (Bernheim 1996; Pardon et al. 2009; Roeland et al. 2014). One of author JB's cases even more suggests complex motives. After a long process of persuading the caregiver team to help him die, this advanced pancreatic cancer patient on total parenteral nutrition, but in no physical pain, had been entrusted with, when he decided the time had come, switching a three-way valve himself from his regular perfusion to one with a rapid-flow lethal dose of barbiturates. He eventually declined to do so. Not that he had changed his mind: He was adamant that the doctor had to switch the vallve. Actually, this particular, strong-willed intellectual's apparent preference for "passivity" may have been ambiguous: It can on the contrary have been a manifestation of active control. Because his suffering had been only mental, not physical, his caregivers had been reluctant to grant him euthanasia. Overcoming their misgivings had given him considerable satisfaction, which was documented in the evolution of his ratings of subjective well-being by Anamnestic Comparative Self Assessment (Bernheim 1999b). This case also raises the question to what extent physicians can accept to be instrumentalised by patients.

\section{Question Five: How Is the Belgian Model Organised? What Is "Integral Palliative Care"? What Else Is "Integral End-of-Life Care"?}

MA: How has Belgium organised end-of-life care and how does the Belgian model work? What is the difference between conventional and so-called 
The Belgian Model of End-of-Life Care

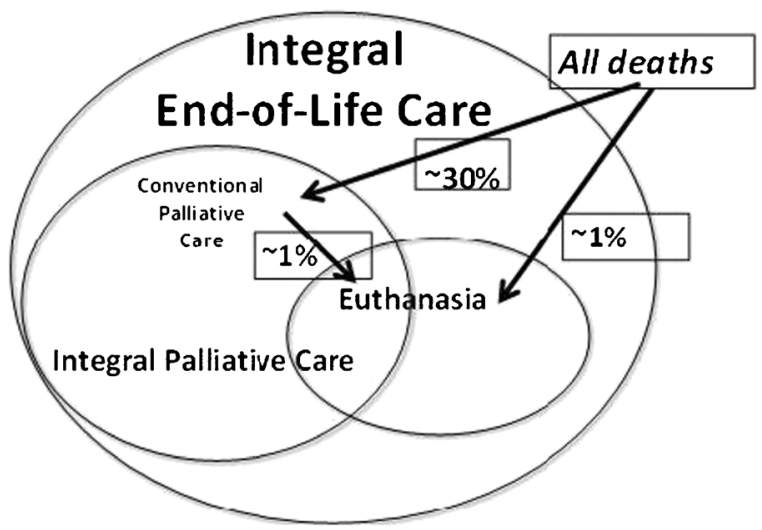

Fig. 2 The Belgian model of end-of-life care

Belgian "integral palliative care"? And what is the place of "integral palliative care" in "integral end-of-life care"?

Integral palliative care as conventional palliative care that has embraced and embedded euthansaia (Federatie Palliatieve Zorg Vlaanderen 2003; Vanden Berghe et al. 2013) is illustrated in Fig. 2. The Venn diagram shows the qualitative relationships between types of care: Integral palliative care is conventional palliative care (as practised in countries without legal euthanasia) offering also the option of euthanasia. A reasonable estimate based on the 2007 study of Belgian patients during the last three months of their lives is that about 30 percent of all deaths (41 percent of all non-sudden deaths) are preceded by organised multidisciplinary palliative care, and that about 2 percent die with euthanasia, half of them after a palliative care pathway (Van den Block et al. 2009). ${ }^{3}$ Significant numbers of caregivers are conscientious objectors to euthanasia, which is respected by the law and in practice. Patients by law have a right to palliative care and to request euthanasia, but individual doctors freedom of conscience are always entitled to exercise their right to conscientious objection, and therefore not to participate in any form of assistance to die. The physicians refusing to carry out euthanasia

\footnotetext{
3 This study result reflects the situation in 2007; a recent estimate is 50 percent of all deaths (Vanden Berghe et al. 2013). Also Catalonia has a high penetrance of palliative care (Gómez-Batiste et al. 2012), but no similar data are available in other countries. Even so, in Belgium referral to palliative care is probably still suboptimal (Beernaert et al. 2013), and futile disease-directed treatment has not disappeared.
}

must in due time inform their patient of this, giving also the reasons for their refusal (Article 14 of the Euthanasia Law). If the refusal is on medical grounds, this must be documented in the patient's file. They have a legal duty to refrain from futile medical treatment, but not to engage in euthanasia (Bernheim, Vansweevelt, and Annemans 2014).

As the only palliative care organisation in the world to have done so, the Palliative Care Federation of Flanders (FPCFl) is an innovating outlier, a heretic according to some (Jaspers, Muller-Busch, and Nuack 2009; Materstvedt 2013). The FPCF1 prefers the term "euthanasia accompaniment" over "integral palliative care" (Vanden Berghe et al. 2013). It does not have and does not claim a monopoly on the provision of euthanasia. This is because there are patients whose disease is fatal and whose suffering is irreversible, who have a wish for euthanasia but do not need or want multidisciplinary conventional palliative care. Many such patients have advanced neurodegenerative diseases, and their palliative care is usually undertaken by neurological services in Belgium. Therefore, the national model of integral end-of-life care is one comprising palliative care (including optional euthanasia) and assisted dying without involvement of multidisciplinary palliative care.

In Flanders, physicians, many of whom are unfamiliar with the regulations and the clinical practice of euthanasia, can call on their colleagues from the LifeEnd Information Forum (LEIF) for both the legally required second-opinion consultation by an independent physician and for technical assistance in the practice of euthanasia. In both the French-speaking Belgium Forum EOL (End of Life) and the Netherlands SCEN (Steun en Consultatie voor Euthanasie Nederland) doctors are available for this service (Van Wesemael et al. 2009a, 2009 b 2012). The consultation by an independent physician that is legally required is remunerated in the Netherlands, but not yet in Belgium. More than 400 Flemish physicians have undertaken the LEIF training since 2003, the palliative care component of which is entrusted to the Palliative Care Federation of Flanders. LEIF physicians are known to explicitly endorse euthanasia as one more option at the end of life. About 1,000 physicians have followed palliative care training since 1998, partly theoretical, but mainly by means of case conferences and clinical placement experience. The objective of training in palliative care is "emancipatory," 


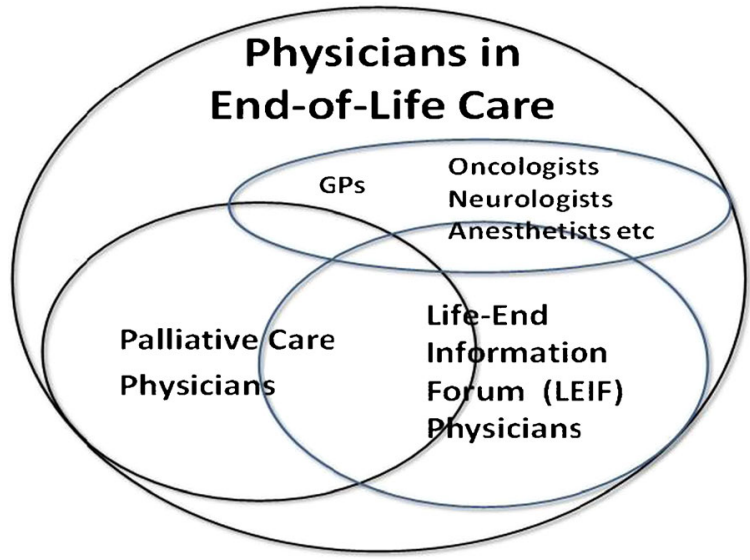

Fig. 3 Overlapping affiliations of Belgian physicians involved in end-of-life care

aiming at "empowerment": In the interest of continuity of care to patients the FPCFl tries to train non-specialist caregivers (while offering them and their patients assistance in the form of specialised paramedical home care), so that only exceptionally would specialist palliative care services need to take over care. Such a basic or "first-line" model has recently been advocated in the United States (Quill and Abernethy 2013). Contrary to LEIF physicians, individual palliative care physicians are not required to accept and practice euthanasia themselves, but at the aggregate level of organisations, just as LEIF, the FPCFl aims to help the patient with all options. The Belgian (or at least Flemish) model of comprehensive end-of-life care thus offers euthanasia both within and outside organised multidisciplinary palliative care (see Fig. 2).

Integral palliative care is thus conventional palliative care (as practised in countries without legal euthanasia) with an integrated possible choice of the option of euthanasia. Among non-palliative care specialists, it is mainly oncologists, followed by anaesthetists and neurologists, who perform euthanasia (Fig. 3). However, about half of euthanasia episodes take place in the patient's home, usually by GPs and, in the majority of cases, after the intervention of a palliative care team (Van den Block et al. 2009; Chambaere et al. 2010a). Many palliative care physicians are also LEIF physicians. A majority of palliative care physicians adhere to comprehensive palliative care (i.e., including euthanasia), the remainder only conventional palliative care (Fig. 3).

For the Palliative Care Federation of Flanders (FPCFl), euthanasia is the ultimate modality of comprehensive integrated palliative care practice and it opposes an either/or mutually excluding duality (Federatie Palliatieve Zorg Vlaanderen 2003, 2007; Vanden Berghe et al. $2013^{4}$ ). For both the FPCFl and LEIF, the patient has the right to know his or her individual physician's attitude towards euthanasia. LEIF physicians are known to be open to euthanasia, but for palliative physicians, it may not be clear. Therefore, physicians with conscientious objections are required to inform their patients in due time, so as not to have to let them down at the end of a palliative care pathway (Federatie Palliatieve Zorg Vlaanderen 2003; Bernheim et al. 2008; Vanden Berghe et al. 2013). LEIF physicians posit that for patients who have no need for multidisciplinary palliative care (e.g., most of those with neurodegenerative diseases in Belgium because their care is organised otherwise) or for patients who decline palliative care, an organisation is needed to offer competent euthanasia without the intervention of palliative care, and they are available for this. A recent 2012 addition to end-of-life services is the ULteam ("UL" stands for Uitklaring Levenseindevragen or the clarification of end-of-life issues; see http://www.ulteam.be/), a collective of professionals who offer consultation and deliberation to patients who cannot find a hearing for their end-of-life concerns or whose wishes were turned down. Many of these are psychiatric patients (see the ULteam website). Notorious controversial euthanasia cases granted after many months of scrutiny and deliberation by the ULteam on grounds of irreversible mental suffering were those of congenitally deaf twin brothers who were also going blind (Siebold 2013) and a man named Nathan Verhelst following several failed sexreassignment surgeries (Gordts 2013). However, a euthanasia request by a sexual offender who had been detained for 30 years for rape and murder was put on hold because palliative treatment had not been provided: The patient had asked for expert palliative psychiatric treatment that was available only in the Netherlands, and the Belgian penitentiary system had failed to provide it (Leestmans 2013). The patient has brought his case before a court (Vanhecke 2013). Assessments of such

\footnotetext{
${ }^{4}$ The Vanden Berghe et al. (2013) paper, otherwise very informative, is inaccurate by ignoring quantitative data when it states that Flemish palliative care physicians practise "euthanasia accompaniment," but only "very occasionally" carry out euthanasia. The latter reflects author M. Desmet's personal position, but is contradicted by epidemiological data (Van den Block et al. 2009) and rightly picked up as inconsistent by Randall (2013).
} 
cases should not be formed until reliable evidence about their conditions is available.

Overall, about half of euthanasia requests are effectively carried out (Van Wesemael et al. 2011), slightly more than in the Netherlands (Jansen-van der Weide et al. 2005). In Belgium only 5 percent were refused, because the legal conditions were not met or because the doctor was a conscientious objecter, and 10 percent of requests were withdrawn. In 23 percent of cases, the patient had died before euthanasia could be performed, suggesting belated requests, but probably also procedural fastidiousness or procrastination on behalf of some physicians (Van Wesemael et al. 2011). Only anecdotal information is available on the extent of refusal because of conscientious objection of caregivers. In the Netherlands it was found that patients who were denied euthanasia did not forsake their wish to die, but often subsequently remained silent about it (Pasman et al. 2013). However, an unknown but non-negligible number of patients whose request was turned down went on to violent suicide. De Einder, a foundation aiming to prevent this by providing guidance for suicide was created (see http://deeinder.nl/english/), and the Dutch Society for Voluntary Euthanasia recently created mobile professional teams for euthanasia in patients' homes and an "End-of-Life Clinic" (see http://www.nvve.nl/).

Belgium is also the first country where, under strict conditions, patients with irreversible catastrophic neurological conditions whose request of euthanasia has been granted can can give added meaning to their life and death by directing to donate their (intact) organs for multiple transplantations, according to Eurotransplant guidelines (Eurotransplant 2008; Ysebaert et al. 2009, Van Raemdonck et al. 2011; Bruno et al. 2011).

Unlike in the Netherlands, citizenship is not a legal requirement for euthanasia in Belgium, but euthanasia is conditional on a profound patient-doctor relationship. There is so far no evidence of "euthanasia tourism."

\section{Question Six: Does the Belgian Model Have International Relevance?}

MA: How relevant and potentially reproducible is the Belgian experience internationally? Is the Belgian model a heresy, an experiment, or a prototype of things to come? What societal philosophical principles underlie it?
The international reactions to the Belgian model are diverse and often emotional, ranging from revulsion to acclaim. We submit that the Belgian experience is meaningful both on the level of societal philosophy and pragmatically. The societal philosophical message is that governments and dominant religions may at best regulate but should not repress implementations of initiatives that are consistent with the Universal Declaration of Human Rights (UDHR) (1948), such as selfdetermination in procreation and choosing to have assistance to die. The UDHR is more than the intellectual brainchild of the Enlightenment. To the extent that it encapsulates mastery of one's destiny, conforming to the UDHR can be shown to, at the aggregate level of nations, be a precondition for people's happiness (Heylighen and Bernheim 2000a). (Cultural relativists might claim unassailable rights for any minority or group within society. We disagree because some minorities or even majorities can be [temporarily] misguided in fundamental ways.)

The pragmatic message is that in other countries the proponents of legal euthanasia might do well to promote palliative care and that the advocates of palliative care may have no valid case to oppose the legalisation of euthanasia, if only because the latter was a major boost for palliative care in the Netherlands and Belgium (Bernheim et al. 2014). It should be noted that our neighbour Luxembourg was the next country after Belgium to concomitantly enact twin laws generalising PC and legalising euthanasia in March 2009, and in June 2014 Québec adopted similar provisions (Assemblée Nationale du Québec 2014). The knowledge of the Benelux provisions for the end of life will probably contribute to more patient requests for assisted dying in other countries. Palliative care and other physicians will most likely find it increasingly difficult to let their patients down by offering only palliative sedation (Sterckx, Raus, and Mortier 2013) or sending them on to travel to Switzerland or Belgium. The recommendation of the Federation Palliative Care Flanders to its foreign colleagues is: "Get involved" (Vanden Berghe et al. 2013).

This said, the "translation" of scientific evidence into health policy is a complex process that is subject to inertia and cultural impediments (Liverani, Hawkins, and Parkhurst 2013). The eventual acceptance of medical ethical developments after prolonged professional and political opposition is not without historical precedents, 
for example, contraception, assisted procreation, and abortion. Just as the European Association for Palliative Care (EAPC) so far rejects legal euthanasia (Materstvedt et al. 2012), the International Federation of Gynecology and Obstetrics (FIGO) has opposed abortion for many decades. However, in 1998 it took the position that all women must have access to professionally performed abortion. FIGO now states "neither society, nor members of the health care team responsible for counseling women, have the right to impose their religious or cultural convictions regarding abortion on those whose attitudes are different" (FIGO 2013, 104) and concludes that "the Committee recommend[s] that after appropriate counselling, a woman [has] the right to have access to medical or surgical induced abortion, and that the health care service [has] an obligation to provide such services as safely as possible" (FIGO 2013, 105; Erdman et al. 2013). But also here, in addition to philosophical motives, pragmatic motives have been operating: Another important objective of FIGO was to lift abortion out of clandestine illegal activity, to let it be performed in medically correct conditions and so ensure that abortion is safe and accessible. Similarly, illegal clandestine end-of-life practices, performed without peer control, as documented in Belgium before the euthanasia law and elsewhere (Kuhse et al. 1997; Deliens et al. 2000; Mitchell and Owens 2003) can be considered more worrying than even imperfectly regulated legal euthanasia. Evidently, bioethical evolutions come about more readily when ethical and pragmatic motives coincide and operate synergistically.

It seems likely that in the future more countries will legalise and regulate euthanasia and that, over time, international organisations such as the EAPC will endorse euthanasia.

\section{Question Seven: Why Did Synergy Between Palliative Care and Euthanasia First Emerge in Belgium?}

MA: Why have the development of palliative care and the drive for legal euthanasia been synergistic only in Belgium? How did Belgian "exceptionalism" come to be?
That Belgium is one of the countries with the most developed palliative care systems (Centeno et al. 2007; Chambaere et al. 2011a; Bernheim et al. 2014) and the third country to have legally regulated euthanasia ${ }^{5}$ is not paradoxical, as we have tried to make clear above, but it may also not be accidental. The explanations for this as yet unique ${ }^{6}$ synergy are undoubtedly complex. We propose some hypotheses.

A first element that may have played a part is Belgians' high level of confidence in their health care system, amongst the highest in Europe (Halman 1999). Indeed, legal euthanasia may be deemed frightening and ominous if the public's confidence in their health care systems is poor. As proven, this is not the case in Belgium, where in 2008 this confidence rate rose to 91.2 percent, just below Iceland (the highest in Europe), followed by Luxembourg with 87.1 percent. This suggests that the 2002 law on euthanasia has not eroded confidence in the health care system, as is sometimes surmised abroad.

As a second factor, the group of caregivers who were active in both euthanasia and palliative care constituted a bridge between the two movements (Bernheim 1990, 1996; Distelmans 2010). We know of no other country where the initiators of palliative care also promoted legal euthanasia.

This leads to another question: Why was it in Belgium that health care workers first took this position? We suspect this is a result of a more general characteristic of this country: ethical modernity, in conformity with contemporary philosophical views that are widely respected in Belgium and whose essence is propagated in schools, social organisations, the media, and politics

\footnotetext{
5 The Benelux countries were preceded by Australia's Northern Territory's Rights of the Terminally Ill Act in 1998, which however was subsequently overturned by the Commonwealth of Australia's Euthanasia Laws Act.

${ }^{6}$ Excepting Luxembourg and Québec (Assemblée Nationale Québec 2014). It should be noted that the Dutch model is rather different: The momentum for euthanasia grew much earlier and wholly independently from PC. Medical professional organisations and the judiciary played a much more important role than in Belgium. In the early 1990s they together developed a nonprosecution policy of "regulated tolerance": Euthanasia was not prosecuted if precise rules of prudent practice laid down by the Royal Dutch Medical Association were observed. These are the conditions that in 2002 became the law. PC developed later in the Netherlands than in Belgium. It has since strongly expanded, reaching, like Belgium, a level roughly on a par with the United Kingdom, the cradle of PC and its benchmark country (Chambaere et al. 2011a; Bernheim et al. 2014).
} 
(Engelhardt 1991; Rawls 1992; Hösle 1997; Heymans 2006; Nussbaum 2008; Vermeersch and Braeckman 2008). This modernity manifests itself both at the macro-level of society and at the micro-level of individual behaviour.

A manifestation of active institutional pluralism was that the Federal Advisory Committee for Bio-ethics issued a pivotal report on euthanasia in 1997, with four clear options (prohibition, a priori regulation, a posteriori regulation, and full liberalisation). This was a sober reflection of logical alternatives and of the real diversity of respectable views. It became the basis for decisions by the national assembly, whose majority chose the third option (Raadgevend Comité voor Bioethiek 1997). Such openness was only possible because the advisory board had a pluralistic composition. Effective pluralism was undoubtedly promoted by the fact that, in Belgium, secular humanism ("free-thinking"), like organised religions, is officially recognised as a belief system and represented in advisory bodies.

However, this pluralism is more than institutional: It has also been internalised at an individual level by much of the population. Irrespective of personal worldview, a great many citizens embrace pluralism and adhere to the ethical modernity of secular humanism. (Secular humanism is understood here to be as that suggested by writers such as H.T. Engelhardt, a physician and a philosopher: an ethics of separation between the personal and the public domain, a core ethics originating in the Enlightenment, positing a common language between "moral foreigners" [Engelhardt 1991].)

Other indications of this abound. Many Catholic intellectuals (e.g., Lenaers 2001) and health care workers (as well as much of the general public) hold individual autonomy and responsibility in the highest esteem. Catholic physicians (most of whom prefer to call themselves "Christian" when given the choice) abbreviate lives no less than their free-thinking colleagues when it is upon patients' request, and they tend to do less (compassionate) life abbreviation without explicit request (Deliens et al. 2000; Bernheim 2002). It is probable that this Catholic modernity is connected with the enthusiasm for the concept of "personalism" as proposed by Catholic thinkers such as Mounier (1949), Ladrière (2004), Janssens (1957), Dondeyne (1974), and Schillebeeckx (1982) at the Dutch- and French-language Catholic universities of Leuven/Louvain, who together have trained about half of Belgian physicians. As a result of such progressive attitudes, respect by "free-thinkers" for modern religious thought has increased (e.g., Bernheim 2002). The philosopher Leo Apostel's "atheistic religiosity" was seminal in this respect (Apostel 1998). In May 2013, Christian de Duve, an emeritus professor of the Université Catholique de Louvain and Nobel laureate of medicine, ailing but not moribund, chose "rational" death by euthanasia at the age of 95 after giving a valedictory interview announcing and justifying his decision.

The Belgian model of end-of-life care is only one of the practical manifestations of ethical "modernism." Belgium also has for many years had gay marriage, a liberal legislation on embryo research, and an opt-out law on organ donation that yields amongst the highest per capita number of organ donations per year in the world (Farrell, Price, and Quigley 2011; Gómez et al. 2012).

\section{Question Eight: What Are the Belgian Model's Remaining Problems and Failings?}

MA: This interview appears to draw a rather rosy picture of the Belgian model so far, Are there no problems with palliative care and euthanasia in Belgium? Can you identify shortcomings and points of dissent?

Undoubtedly there are still shortcomings, bottlenecks, controversies, open research questions, and solutions that are worth considering.

\section{Semantic}

A main condition for euthanasia in the Benelux laws is "unbearable" suffering. This is actually a slightly unfortunate misnomer. "Unbearable" is an objective notion, while it is the subjective assessment by the patient that matters most. The objective measurement of suffering is still in its infancy (Deschepper et al. 2013) and no one is in a position to call someone else's suffering bearable or not (Dees et al. 2010). The public, most physicians, and the Control and Evaluation Commission of Euthanasia interpret this term in the euthanasia legislation to mean suffering that is no longer tolerated by the patient. 
Restricting Legal Euthanasia to Fatal Diseases

Loss of dignity and independence, affliction with a number of chronic incurable ailments ("chronic multiorgan failure"), together with a sense of having lived one's life can constitute a state of existence that is not acceptable to the person concerned, although it may not be "objectively" unbearable. Dutch qualitative research has shown that some people who considered "their life completed" and requested euthanasia did not themselves call their suffering "unbearable" (e.g., they could still read a book or watch television), yet did not want to go on living in their condition (Pasman et al. 2009). Such situations can be excruciating, irreversible, and hopeless. Euthanasia is then not legal because the diseases are not lethal. It is also problematic that some consider such requests to be the result of a mental disorder that makes the applicant incompetent or confuse profound sadness with clinical depression (Szmukler 2014).

\section{Funding and Fees}

The funding of PC is still not always adequate, certainly for hospitals, nursing homes, and day care centres, and, unlike in the Netherlands, the legally required consulting doctors, including LEIF physicians, still receive no compensation. An advantage of the integration of basic palliative home care in Belgium's national health insurance, characterised by "fee for service" and "free access," is that it is demand-driven. Basic palliative home care thus accounts for most of the yearly 10 percent increase in overall funding of PC (Bernheim et al. 2014). However, specialised PC in hospitals and in home care must rely on lump grants that have not kept pace with the increasing workload due to increased demand, including more frequent work-intensive requests of euthanasia (Vanden Berghe et al. 2013).

\section{Evading Requests and Denying Euthanasia}

LEIF physicians still encounter cases where a valid and repeated request is met with evasion or procrastination and/or ends in unrequested continuous deep sedation. Also some health care institutions forbid their staff to practise euthanasia. This may result in painful consecutive referrals. Opposition and/or intuitive aversion to euthanasia may hide behind procedural fastidiousness, and deep sedation can be a means to smother existential distress and stifle patient wishes. Deep sedation in such circumstances has been called "the pharmaceutical straitjacket" (Camisole de force médicamenteuse). The Federatie Palliatieve Zorg Vlaanderen (2012) has issued guidelines for ethical palliative sedation.

Cases of "Slippery Slope" and Denial of Patient Rights

A preliminary note on "slippery" slope is in order. This usually denotes an irreversible bad evolution that was not originally intended (van der Burg 1991). The key terms are "bad" and "irreversible." Now, both an evolving world and favourable experiences with an innovation may actually make an originally unintended development good instead of bad. (An example: When in the 19th century the census suffrage was liberalised, the "slippery slope" led to women voting.) As for "irreversibility," bad experiences can lead to the reversal of enfranchisements. (A recent example: the tendency to reverse the deregulation of banks). When considering the alleged "slippery slope" effects of legal euthanasia, these caveats must be kept in mind. Although amongst the several thousands of cases reported to the Control and Evaluation Commission of Euthanasia about 20 percent gave rise to further inquiries, none was so far referred to the public prosecutor. The Commission appears to be lenient on minor deviations from the law (such as absence of a written patient request or of written consultant's findings) that are clarified after receiving satisfactory responses to its inquiries. Also because really problematic cases may not be reported, "toothless" control has been denounced by critics of the Belgian model (Pereira 2011; Cohen-Almagor 2013). However, it must be remembered that before the law there was no public control at all of the 4 percent of clandestine physician-assisted deaths, most of which, at that time, were without a patient request (Deliens et al. 2000; Chambaere et al. 2011b).

Most important, probably: The novel openness of communication on end-of-life issues and the transparency of the procedure make plausible that the control by peers and the public is very effective. The media have reported a few cases of complaints by relatives, but they related to non-involvement of the family in the decisionmaking and to allegedly abusive deep continuous sedation without consent (Sterckx, Raus, and Mortier 2013). No case of euthanasia due to lack of access to palliative care is on record. If this happened, there would likely be a public outcry. In contrast, it can be suspected that a fraction of the deep continuous sedations, which 
spectacularly increased from 8.2 percent of deaths in 1998 to 14.5 percent in 2007 (Chambaere et al. 2011b), is problematic. This practice, which is often the physicians' rather than the patients' preference, belongs to the physicians' sovereign judgment, and is wholly unregulated. It is very prevalent in nursing homes where the provision of professional palliative care is too often lacking. It may in some cases reflect failure of effective palliative care and/or refusal of euthanasia. The Vrije Universiteit Brussels' (VUB) University Hospital, hoping to set an example, has introduced a mandatory reporting procedure for cases of terminal sedation.

\section{The Adherence to Legally Required Procedure} Appears Sometimes Incomplete

In 2007 , in 20 percent of cases that were technically classified as euthanasia by the investigators of death certificate studies (though not necessarily perceived as euthanasia by the surveyed practitioner and not euthanasia for the $\mathrm{law}^{7}$ ) no colleague was reported to have been consulted, as legally required for euthanasia (Chambaere et al. 2010a). Also because too many cases were not reported to the Control and Evaluation Commission, It was concluded that there is more need for more continued education of Belgian physicians (Smets et al. 2012). It has been alleged that some hospitals there might have been an exceptional case of euthanasia that was carried out in a manner that was compliant with legal requirements, but performed in an impersonal and routine way (e.g., personal communication to author JB by Bert Vanderhaeghen, a university hospital chaplain). This would be contrary to the view of euthanasia as the ultimate culmination of a deep caregiver-patient relationship (colloque singulier). If "perfunctory

\footnotetext{
${ }^{7}$ A case was recorded as "euthanasia" in the strictly anonymous epidemiological studies when the death-certifying physician had responded in the affirmative to the questions of (1) explicit patient request, (2) (potentially) lethal drug administration, and (3) intention to hasten death (Deliens et al. 2000; van der Heide et al. 2003). If there had not been a (reitated) explicit request, the case was classified as "life ending act without explicit request". However, this may for instance have occurred for the death struggle of an in extremis suffocating or agitated patient who had previously requested a physician-assisted death, with no time or opportunity to consult a colleague because it happened during the night and in the patient's home. Few would dispute the ethical legitimacy and clinical advisability of such an intervention. This is just to illustrate that legal regulations cannot capture all clinical situations. Therefore, no disproportionate opprobrium need be attached to such quantitatively limited deviations from the letter of the law.
}

euthanasia" became more than highly exceptional and if any occurs and the public developed an impression of euthanasia being undertaken in a casual or uncaring way, this would constitute a real practical slippery slope phenomenon. It would likely erode confidence in medicine and discredit euthanasia. Such cases are have not given rise to complaints or prosecutions, and probably so rare that they have not affected public satisfaction with the Belgian model. ${ }^{8}$ At any rate, there is no evidence of any shift to casual or uncaring euthanasia.

\section{Technical Performance}

The performance of euthanasia requires training, including in considering it as part of "integral" palliative care, and thus an ability to deal with all aspects of end-of-life care, including how to bring about death without failure and side effects. At the present time only LEIF explicitly provide this training.

\section{Integral End-of-Life Care in the Medical School Curriculum}

Teaching of both palliative care and physician-assisted death as part of the core curriculum of medical students has so far been provided only at the Dutch-language Free University of Brussels (VUB), but the other medical schools, which already teach conventional palliative care, are in the process of catching up. At the post-graduate level, there is an interuniversity course in collaboration with the FPCFl.

\section{Reporting}

In the Netherlands, the estimated percentage of euthanasia cases that are duly reported, as legally required since 2002, increased from 18 percent in 1990 to 41 percent in 1995,54 percent in 2001 , and 80 percent in 2005 (Rurup et al. 2008). In Belgium, the number of

\footnotetext{
${ }^{8}$ There is so far no evidence of any erosion of public support for the Belgian model. On the contrary, in the European Values Study the confidence of Belgians in their health care system rose from 87 percent in 1999 (Halman 1999) to 91.2 percent in 2008, second in Europe only to Iceland (European Values Study 2008). The legalisation of euthanasia, the generalisation of palliative care, and the Patient Rights Bill - probably the most important changes in health care in the past decade - rather seem to have increased the confidence of the public. Not that Belgians are uncritical: Over the same interval they increasingly distrusted, for example, politicians, banks, and the Church.
} 
reported euthanasia cases has increased each year. In Flanders in 2007, slightly more than half the estimated total number of euthanasia cases (as according to the technical definition of the death certificate studies) were reported (Smets et al. 2010). If the trend in reporting continues, about 80 percent of the cases would be reported by now. It must also be remembered that before the law on euthanasia, none of the 4 percent of physcianassisted dying were reported (Deliens et al 2000). One must also note that most unreported cases of euthanasia as defined by "intention to hasten death" in the epidemiological studies were clinically indistinguishable from intensified alleviation of pain and symptoms or terminal sedation. They were not euthanasia in terms of the law because no lethal drugs were used and the physicians themselves labeled their act not as euthanasia, but as symptom treatment (Chambaere et al. 2010a). In French-speaking Belgium, the prevalence of continuous deep sedation is higher and the more rare euthanasia cases are also less often reported. There seem to be cultural differences with Flanders, including more aversion to outside interference in the doctor-patient relationship (Chambaere et al. 2010b; Cohen et al. 2012).

Lack of Regulation of Other End-of-Life Decisions That Might Hasten Death

When decisions are taken not to start or to discontinue life-prolonging treatments, or to commence continuous deep sedation until death, which denies patients the spiritual and affective dimensions of dying, they do not benefit from the rigorous process required for euthanasia. These much more frequent, and barely less radical, endof-life decisions still belong to the physician's unscrutinised prerogatives. The steep increase in incidence of continuous deep sedation may be based more on physician than on patient preferences (Anquinet et al. 2012). Also, doubts have been cast on whether palliative sedation provides perfect comfort (Deschepper et al. 2013). Yet, these unregulated practices equally concern patient autonomy, raise the same ethical issues, and deserve similar precautions as euthanasia.

\section{Minors}

The illegality of life-ending of minors, an empirical reality (Provoost et al. 2005; Pousset et al. 2010), became somewhat less problematic when in February 2014 the Belgian parliament enacted an extension of the euthanasia law to "capable" adolescents (Moniteur Belge 2014). Similar to the concept of so-called "Gillick" competence (Wheeler 2006) in the English common law (where the cut-off is 16 years), for children under 12 their parents are entrusted with decisions, but requests of euthanasia by adolescents who are judged to be capable of making their own decisions can be honoured in the Netherlands since 2002. Only a handful are known to have occurred. After extensive hearings, a majority consensus emerged in the Belgian Senate that some children, especially after a long disease history with an illness such as leukaemia, could be considered competent to make valid requests if, after professional psychological consultation, so judged by the caregiving team. Euthanasia has become legal in case of refractory physical suffering if the minor is determined competent by a panel of professional caregivers and the parents agree. On the basis of a favourable experience with euthanasia in refractory suffering by mental illness, proponents had argued for also including mental illness. There is casuistic evidence that suicidal adult refractory psychiatric patients, after having been assured that a request of euthanasia might at some time in the future be honoured, refrained from further suicidal attempts and did not during a follow-up of several years demand euthanasia. The assurance of a desired death when they would judge the time had come apparently sufficed to keep them alive (Callebert, Van Audenhove, and De Coster 2012). For adolescent psychiatric patients it was surmised that the mere possibility of euthanasia could reduce the alarming rate of suicide among children and adolescents. In the end, refractory mental suffering was excluded because at the age of 18 a mental condition cannot have been treated long enough to be judged hopeless. Christian-democrat spokespersons opposed the extension, wanted a cut-off at age 15 and insisted on emphasising the relational dimension of endof-life decision-making, with more legally enforced involvement of the family and all caregivers. The law was enacted in February 2014, with 86 votes in favour, 44 opposed, and 12 abstentions, an almost identical majority as the 2002 law for adults, and most Christian-democrats and the extreme-right parties still dissenting. This extension of the law to capable adolescents has been denounced as a "logical" slippery slope effect in much of the world media. Critics often misunderstood or misrepresentated the actual changes to the law and disregarded that, everywhere, capable adolescents already can refuse further life-sustainng treatment, and do so frequently (Pousset et al. 2010). They probably also 
included people who would not have disputed the competency for self-determination of e.g. Anne Frank, another child who impressively matured under conditions of existential threat.

\section{Lack of Capacity}

The Belgian law requires competency at the time that euthanasia is provided. Only in cases of irreversible total unconsciousness (e.g., by brain injury) can witnessed advance directives in writing for euthanasia be honoured. Therefore, such advance directives cannot legally be honoured for still conscious patients who because of, for example, a brain tumour or dementia can be suspected not to be fully competent to confirm their previous wish. Thus the suffering caused by the intolerable prospect of future loss of higher cognitive capacity can bring people whose life could still have been enjoyable for quite some time to opt for a premature death (Hevesi 2008; Davis 2014). ${ }^{9}$ Whether advance directives of non-treatment or termination of life can apply also for dementia is hotly debated (de Boer et al. 2010). The Belgian Senate heard testimonies also on this controversial issue in 2013. Lawmakers and health professionals are discussing not so much whether the law needs to be extended, but what effective safeguards can be devised.

\section{Life-Ending Acts Without Explicit Request (LAWER)}

This category of decisions at the end of life, as defined and quantified in the epidemiological studies carried out in the Netherlands and Belgium and also in other European and English-speaking countries where euthanasia is illegal (Kuhse et al. 1997; Mitchell and Owens 2003; van der Heide et al. 2003; Chambaere et al. 2010a), are a major concern of critics of euthanasia (Pereira 2011; CohenAlmagor 2013). In the empirical studies, a death is classified as LAWER if the physician checks boxes denoting that (1) drugs were administered with the explicit intention of shortening the patient's life and (2) the patient did not explicitly request this (van der Heide et al. 2003). In clinical terms, most LAWER cases are found to be for patients in extremis, irreversibly unconscious, and having previously

\footnotetext{
${ }^{9}$ The celebrated writer Hugo Claus died that way, and this was denounced as a "cowardly" act by Cardinal-Archbishop Danneels. The two enjoyed each other's company during vacations in Provence. There probably was an element of tragedy in the classic sense in Danneels' condemnation of his friend's decision.
}

expressed a wish of euthanasia. The estimated abbreviation of survival is very short, relatives are usually consulted, and the drugs used are the same as for palliative sedation, namely opioids, which have no or minimal life-ending potential (López-Saca, Guzmán, and Centeno 2013; Meeussen et al. 2010; Chambaere et al. 2010a). Clinically, just as unreported cases of requested euthanasia (Smets et al. 2010), LAWER cases are therefore very different from euthanasia cases. When in a subsequent question physicians were asked whether they considered a case to be one of euthanasia or life-ending without request, they usually said no and did not feel they had to report them. Most of LAWER cases should probably more realistically be interpreted as "compassionate intended abbreviation of terminal agony" (see Chambaere et al. 2010a).

LAWER, as detected by "intention," is found mainly in Belgium (van der Heide et al. 2003; Chambaere et al. 2010a), Australia (Kuhse et al. 1997), and New Zealand (Mitchell and Owens 2003). In most other countries, physicians would likely deny a wish to hasten death and a similar act would probably be classified as intensified alleviation of pain and symptoms or palliative sedation (van der Heide et al. 2003; Seale 2009). The distinction between the intention of life-ending and compassionate intensification of symptom treatment is often blurred (Douglas, Kerridge, and Ankeny 2008). A reasonable hypothesis is that actual practices are not so different and that these are countries where the culture is more conducive to using the doctrine of double effect (McIntyre 2011). Most importantly, since 1998, the incidence of LAWER has halved in Belgium since the legalisation of euthanasia (Bilsen et al. 2009; Chambaere et al. 2010a), which should allay this concern of a practical slippery slope. Yet one cannot exclude a few objectionable acts, and LAWER, just as palliative sedation, can be problematic when there is no advance directive. An interesting phenomenon is that the liberalisation of euthanasia in the Low Countries seems to have promoted a novel orthodoxy in end-of-life practices and decreased the tolerance for compassionate paternalism when a patient is agonising. In 1934 Dr. Dawson, King George V's personal physician, seems to have had no qualms recording that, in the face of respiratory failure and in the interest of his patient's dignity, he had nudged him over the edge with opiates (Ramsay 1994). But the pendulum between "autonomism" and paternalism may be swinging back: According to some, the current dogma of absolute patient autonomy has overshot and beneficent paternalism at the end of life needs to be reappraised (Roeland et al. 2014). 
Parental Termination of Life

It is difficult to conceive of assistance to die, or indeed conventional palliative care, unless patients are informed of the imminence of their death (Bernheim 1996; Deschepper et al. 2008; Tariman et al. 2010). Some patients express wishes of abbreviation of suffering at the end of their life, but when the time comes, they do not want to be informed of the imminence of their death (Bernheim 1996, 2001; Pardon et al. 2012a). This chosen ignorance prevents patients from being assisted as they might wish if they knew their prognosis. Such situations create a conflict between patient autonomy and physician beneficence. An attempt to resolve such deadlocks by a so-called parental/ filial "physician-patient information and communication covenant" (ICC) has been proposed. Parental is to be distinguished from paternalistic: In the former case it is the patient who takes the initiative to assume a filial position and who asks the doctor to be parental, whereas in the latter it is the doctor's initiative. The parental/filial situation realises what is called "weak" paternalism. A doctor-patient relationship is (strongly) paternalistic only when it is the physician who decides it to be such. The ICC is an agreement on (1) the level of information and degree of joint decision-making that the patient wants and (2) on his or her wishes and advance directives for the end of life. It can best be negotiated early in the physician-patient relationship and is always renegotiable (Bernheim 1996, 2001). Such an approach has been validated by later studies on the preferences of advanced cancer patients for information and involvement in decision-making (Pardon et al. 2012a, b, c).

\section{Consultation for Euthanasia}

The question is unresolved whether physicians who, as the law requires, give a second opinion when a request of euthanasia is processed need to be ad hoc registered specialists, "euthanasia doctors" as it were. In the Netherlands, the Royal Society of Medicine (Koninklijke Nederlandse Maatschappij voor de Geneeskunde, KNMG) appoints Support and Consultation for Euthanasia (SCEN) physicians for this task, which is also a condition for remuneration (Van Wesemael et al. 2009a). Should there be specialised training in Belgium for consultancy about euthanasia requests? This is what LEIF do and propose, arguing (1) that many physicians do not know the law and end-of-life care well enough to give expert advice and (2) that too many valid and repeated requests for euthanasia in practice are still turned down. Or should all physicians be eligible for this role, as the Federation Palliative Care Flanders ( $\mathrm{FPCFl}$ ) favours on the basis of its commitment to empowerment and continuity of care in the integral palliative care model? LEIF and the FPCFl are at loggerheads on this issue. Whatever will be decided, the registered consultant physicians will have to provide proof of expertise and be committed to integral end-of-life care. The value of specific training for the quality of second physician consultation was recently documented (Cohen at al. 2014).

\section{Team Interventions}

LEIF and the FPCFl also differ regarding the desirability of systematically sending in a palliative care team for assessment of requests for euthanasia. According to the "total care" doctrine, team interventions are preferred by the FPCFl. For LEIF, it is up to the attending physician to decide whether a palliative team must be consulted. LEIF considers interventions involving, for example, a psychologist, a physical therapist, and a chaplain or a secular moral counsellor as burdensome for the patient and demeaning for the judgement and dedication of the attending physician. Professional and societal debates on these issues are ongoing.

\section{Question Nine: How Might the Belgian Model Evolve?}

MA: Though the situation in "non-permissive" countries deserves far more concern (e.g., Kuhse et al. 1997; Mitchell and Owens 2003), it is obvious from the above that the Belgian model of end-of-life care still has several loose ends. How can one expect it to evolve?

Should euthanasia and palliative care be further integrated? This is what the Federation Palliative Care Flanders favours, but it is still problematic. Most professionals involved in end-of-life care have a double desire: (1) complete openness of all palliative care organisations to euthanasia and (2) "eu-euthanasia," or maximal care in the performance of euthanasia. In an ideal world, all palliative care practitioners would be LEIF physicians and this would result in generalised integral palliative 
care. For the time being this ideal is still remote, if only because since euthanasia must also be possible outside of organised palliative care (Fig. 2). This is because quite a few Flemish palliative care physicians do not adhere to the pluralistic majority position of the Federation Palliative Care Flanders, but stick to conventional palliative care principles ("no hastening of death") as officially observed in most countries. In short, because not all euthanasia requests fall within the remit of palliative care, not all palliative care workers practice integral palliative care, and those opposed to euthanasia must retain their freedom of conscience, organised palliative care accepts that it does not have a monopoly on euthanasia.

Yet, there is the persisting problem of individual conscientious objectors against euthanasia and particularly within those several hospitals, nursing homes, and palliative units where, for respectable personal reasons, nobody wants to perform euthanasia or, much less respectably, euthanasia is not allowed because of the institution's ideological basis or management. The notion of "conscientious-objector institutions" is criticised because only individual persons, not institutions, can have a conscience and patients do not have a deep relationship with hospital governing boards. When a patient makes a valid request for euthanasia and the attending physician or the institution applies restrictive criteria, then the values of the patient are subordinated to those of the physician or institution. The Dutch pioneer of euthanasia, the late Dr. Piet Admiraal, who himself worked in a Catholic hospital in Delft, said in a lecture that practitioners or institutions who refuse euthanasia "should write this on the front door." The FPCFl, when endorsing euthanasia, prescribed such up-front transparency when it declared that "[c]aregivers have ... every right to set personal ethical boundaries, but they must state these candidly, clearly and above all in due time" (Federatie Palliatieve Zorg Vlaanderen 2003, $\mid 2$ under "Uitgangspunt"). Moreover, some opponents of euthanasia in palliative care also admit that a public notification of opposition to euthanasia is desirable (Pereira et al. 2008).

Conscientious objectors receiving a valid euthanasia request are required to refer the patient to a willing colleague, but as yet this is only an ethical, not a legal, obligation. For abortion, FIGO has a similar guideline (International Federation of Gynecology and Obstetrics 2008). However, for the pre-terminal patient a referral can be a traumatic procedure. An alternative would be that, just as any GP can call on a LEIF doctor, institutions (including palliative care units) where all the doctors have chosen to or must refrain from euthanasia would entrust the patient to a consulting LEIF physician, who would become the ad hoc attending physician. These institutions would thus de facto become pluralistic and law-abiding. Thus, involving LEIF physicians would have a double benefit. First, there would be no social pressure on conscientious objectors to go against their beliefs and perform euthanasia. Second, the "strong" paternalistic pressure on patients to renounce their wish for euthanasia would decrease. Though much less than before the euthanasia law, undoubtedly, this still occurs: Patients can fear that a request for euthanasia would be perceived as a failure and a slap in the face by caregivers whom they need and esteem. Such qualms from patients explain why palliative care physicians, like Sister Léontine, known to be opposed to euthanasia, before the euthanasia law reported hardly ever having received a request for euthanasia (see Zuster Léontine 1995).

\section{Conclusion}

With the twin 2002 laws on palliative care and euthanasia, the Belgian legislature directed that both conventional palliative care and euthanasia would be available to all patients, everywhere in the country, whether in institutions or in their home. Palliative care and euthanasia exist separately side by side when there is no indication for organised palliative care or when the patient does not want palliative care (Fig. 2). For other cases in Belgium, including when the patient has come to consider palliative care futile, palliative care has taken euthanasia on board, and they largely go hand in hand.

In sum, the Belgian model may be heresy for current mainstream palliative care doctrine, but it is a wellfunctioning experiment and probably a prototype of things to come elsewhere. The Belgian model is evolving, and many important issues are the subject of ongoing professional, societal, and political debate. This is a hallmark of Belgian society, whose culture and politics always require a high degree of tolerance and compromise. Although a predominantly Roman Catholic country, there is a tradition of liberalism and secular humanism (of the Engelhardt 1991 type) manifest at all levels of society. These factors all contribute to Belgium's unique approach to the provision of legally sanctioned assistance to die, which many people in other countries support but are so far not allowed to have. 
Acknowledgments We thank Marc Desmet, Jacques Haers, and Jocelyn Downie for their critical comments on erlier drafts. This study was supported by HOA2, Vrije Universiteit Brussel.

\section{References}

Anquinet, L., J.L. Rietjens, C. Seale, J. Seymour, L. Deliens, and A. van der Heide. 2012. The practice of continuous deep sedation until death in Flanders (Belgium), the Netherlands, and the U.K.: A comparative study. Journal of Pain and Symptom Management 44(1): 33-43.

Apostel, L. 1998. Atheïstische religiositeit. Brussels: VUB Press.

Assemblée Nationale du Québec. 2014. Projet de loi n52 : Loi concernant les soins de fin de vie [Bill 52: An Act concerning end of life care]. http://www.assnat.qc.ca/fr/travauxparlementaires/projets-loi/projet-loi-52-41-1.html.

Beernaert, K., J. Cohen, L. Deliens, et al. 2013. Referral to palliative care in COPD and other chronic diseases: A population-based study. Respiratory Medicine 107(11): 1731-1739.

Bernheim, J. 1990. Cognitive revolution, mastership over living and dying. A physician's reflexions on the euthanasia problem [in Dutch]. In In Bio-ethiek: Ethische, medische en wetenschappelijke perspectieven op de morele problemen van biotechnologie, edited by Ch. Suzanne and J. Stuy, 103-109. Brussels: VUB Press.

Bernheim, J.L. 1996. The information and communication covenant between physician and patient, orthothanasia and euthanasia: A cognitive guideline for legal and ethical deadlocks [in Dutch]. In Waardig sterven: Een humanistische visie op euthanasia, edited by L. Desmedt and C. Van Kerckhove, 67-82. Antwerp: De Humanistische Pers.

Bernheim, J.L. 1999a. The cognitive revolution and 21st-century enlightenment: Towards a contemporary evolutionary progressive worldview. In Science, technology, and social science: Einstein meets Magritte: An interdisciplinary reflection on science, nature, art, human action and society, vol. 3, edited by D. Aerts, S. Gutwirth, S. Smets, and L. Van Langenhove, 63-95. Dordrecht: Kluwer Academic Publishers.

Bernheim, J.L. 1999b. How to get serious answers to the serious question: "How have you been?": Subjective quality of life (QOL) as an individual experiential emergent construct. Bioethics 13(3-4): 272-287.

Bernheim, J. 2001. The doctor's dilemma between patient autonomy and physician beneficence at the end of life. II. A physician-patient information and communication covenant (ICC) as a procedural-ethical solution [in Dutch]. Ethiek en Maatschappij 4(1): 114-121.

Bernheim, J. 2002. Catholics, free-thinkers, lighthouses and navigation systems: Reflexions on the euthanasia debate [in Dutch]. Streven, June: 523-537.

Bernheim, J.L., R. Deschepper, W. Distelmans, A. Mullie, J. Bilsen, and L. Deliens. 2008. Development of palliative care and legalisation of euthanasia: Antagonism or synergy? British Medical Journal 336(7649): 864-867.

Bernheim, J.L., L. Van den Block, J. Cohen, et al. 2012. The Belgian model of comprehensive end-of-life care: Palliative care and euthanasia as complementing, non-conflicting developments. I. Historical, epidemiological and regulatory data [in Dutch]. Tijdschrift voor Geneeskunde 68(11): 539548.

Bernheim, J.L., K. Chambaere, P. Theuns, and L. Deliens. 2014. State of palliative care development in European countries with and without legally regulated physician-assisted dying. Health Care 2(1): 10-14. doi:10.12966/hc.02.02.2014.

Bernheim, J.L., T. Vansweevelt, and L. Annemans. 2014. Medical futility and end-of-life issues in Belgium. In Medical futility: $A$ cross-national study, edited by A. Bagheri, 59-83. London: World Scientific and Imperial College Press.

Bilsen, J., J. Cohen, K. Chambaere, et al. 2009. Medical end-oflife practices under the euthanasia law in Belgium. The New England Journal of Medicine 361(11): 1119-1121.

Broeckaert, B., J. Gielen, T. Van Iersel, and S. Van den Branden. 2009. Palliative care physicians' religious/world view and attitude towards euthanasia: A quantitative study among Flemish palliative care physicians. Indian Journal of Palliative Care 15(1): $41-50$.

Bruno, M.-A., J.L. Bernheim, D. Ledoux, F. Pellas, A. Demertzi, and S. Laureys. 2011. A survey on self-assessed well-being in a cohort of chronic locked-in syndrome patients: Happy majority, miserable minority. BMJ Open 1(1): e000039. doi: 10.1136/bmjopen-2010-000039.

Bülow, H.H., C.L. Sprung, M. Baras, et al. 2012. Are religion and religiosity important to end-of-life decisions and patient autonomy in the ICU? The Ethicatt study. Intensive Care Medicine 38(7): 1126-1133.

Callebert, A., C. Van Audenhove, and I. De Coster. 2012. Euthanasia in unbearable mental suffering [in Dutch]. Leuven: Acco.

Canadian Hospice Palliative Care Association. 2010. CHPCA issues paper on euthanasia, assisted suicide and quality endof-life care. http://www.chpca.net/uploads/files/english/ public_policy_advocacy/PAD_Issues_Paper_April_24_ 2010 Final.pdf. Accessed June $\overline{2}, 2014$.

Centeno, C., D. Clark, T. Lynch, et al. 2007. Facts and indicators on palliative care development in 52 countries of the WHO European region: Results of an EAPC Task Force. Palliative Medicine 21(6): 463-471.

Chambaere, K., J. Bilsen, J. Cohen, B.D. Onwuteaka-Philipsen, F. Mortier, and L. Deliens. 2010a. Physician-assisted deaths under the euthanasia law in Belgium: A population-based survey. Canadian Medical Association Journal 182(9): 895-901.

Chambaere, K., J. Bilsen, J. Cohen, E. Raman, and L. Deliens. 2010b. Differences in performance of euthanasia and continuous deep sedation by French- and Dutch-speaking physicians in Brussels, Belgium. Journal of Pain and Symptom Management 39(2): e5-e7.

Chambaere, K., C. Centeno, E.A. Hernandez, et al. 2011a. Palliative care development in countries with a Euthanasia law: Report for the Commission on Assisted Dying. Milan: European Association for Palliative Care. http://www. commissiononassisteddying.co.uk/wp-content/uploads/ 2011/10/EAPC-Briefing-Paper-Palliative-Care-in-Countrieswith-a-Euthanasia-Law.pdf.

Chambaere, K., J. Bilsen, J. Cohen, B.D. Onwuteaka-Philipsen, F. Mortier, and L. Deliens. 2011b. Trends in medical end-of-life decision making in Flanders, Belgium 1998-2001-2007. Medical Decision Making 31(3): 500-510. 
Commission Fédérale de Contrôle et d'Évaluation de l'Euthanasie. 2012. Cinquieme rapport aux chambres législatives (années 2010-2011) [in French]. Brussels: Secrétariat de la Commission. http://www.health.belgium. be/filestore/19078961_FR/Rapport\%202012\%20fr.pdf. Accessed June 25, 2014.

Cohen, J., J. van Delden, F. Mortier, et al. 2008. Influence of physicians' life stances on attitudes to end-of-life decisions and actual end-of-life decision-making in six countries. Journal of Medical Ethics 34(4): 247-253.

Cohen, J., Y. Van Wesemael, T. Smets, J. Bilsen, and L. Deliens. 2012. Cultural differences affecting euthanasia practice in Belgium: One law but different attitudes and practices in Flanders and Wallonia. Social Science and Medicine 75(5): 845-853.

Cohen, J., Y. Van Wesemael, T. Smets, et al. 2014. Nationwide survey to evaluate the decision-making process in euthanasia requests in Belgium: Do specifically trained 2nd physicians improve quality of consultation? BMC Health Services Research 14(1): 307. doi:10.1186/1472-6963-14-307.

Cohen-Almagor, R. 2013. First do no harm: Pressing concerns regarding euthanasia in Belgium. International Journal of Law and Psychiatry 36(5-6): 515-521.

Davis, D.S. 2014. Alzheimer disease and pre-emptive suicide. Journal of Medical Ethics 40(8): 543-549. doi:10.1136/ medethics-2012-101022.

de Boer, M.E., C.M. Hertogh, R.M. Dröes, C. Jonker, and J.A. Eefsting. 2010. Advance directives in dementia: issues of validity and effectiveness. International Psychogeriatrics 22(2): 201-208.

Dees, M., M. Vernooij-Dassen, W. Dekkers, and C. van Weel. 2010. Unbearable suffering of patients with a request for euthanasia or physician-assisted suicide: An integrative review. Psychooncology 19(4): 339-352.

De Keyser, E. 2003. Euthanasia: A medical act? [in Dutch]. Nieuw Juridisch Weekblad 10(45): 1067-1073.

Deliens, L., F. Mortier, J. Bilsen, et al. 2000. End-of-life decisions in medical practice in Flanders, Belgium: A nationwide survey. The Lancet 356(9244): 1806-1811.

Deliens, L., and G. van der Wal. 2003. The euthanasia law in Belgium and the Netherlands. The Lancet 362(9391): 12391240.

Deschepper, R., S. Laureys, S. Hachimi-Idrissi, J. Poelaert, W. Distelmans, and J. Bilsen. 2013. Palliative sedation: Why we should be more concerned about the risks that patients experience an uncomfortable death. Pain 154(9): 1505-1508. doi: 10.1016/j.pain.2013.04.038.

Deschepper, R., J.L. Bernheim, R. Vander Stichele, et al. 2008. Truth-telling at the end of life: A pilot study on the perspective of patients and professional caregivers. Patient Education and Counselling 71(1): 52-56.

Desmet, M. 2000. Is suffering inhuman? [in Dutch]. Tielt: Lannoo.

de Zulueta, P. 2013. Compassion in healthcare. Clinical Ethics 8(4): 87-90.

Distelmans, W. 2010. Dying with dignity, 6th rev. ed. [in Dutch]. Antwerpen-Amsterdam: Houtekiet.

Dondeyne, A. 1974. Miscellanea Albert Dondeyne: Godsdienstfilosofie; philosophie de la religion. Leuven: Leuven University Press.

Douglas, C., I. Kerridge, and R. Ankeny. 2008. Managing intentions: The end-of-life administration of analgesics and sedatives, and the possibility of slow euthanasia. Bioethics 22(7): 388-396.

Downie, J., K. Chambaere, and J.L. Bernheim. 2012. Pereira's attack on legalizing euthanasia or assisted suicide: Smoke and mirrors. Current Oncology 13(3): 133-138.

Engelhardt, H.T. 1991. Bioethics and secular humanism: The search for a common morality. London: SCM Press.

Erdman, J.N., T. DePiñeres, and E. Kismödi. 2013. Updated WHO guidance on safe abortion: Health and human rights. International Journal of Gynaecology and Obstetrics 120(2): 200-203.

European Values Study. 2008. 4th EVS wave 2008 (ZA4800). Cologne: GESIS Data Archive. http://www.gesis.org/en/ services/data-analysis/survey-data/european-values-study/ 4th-wave-2008/.

Eurotransplant. 2008. Report of the Board and central office of Stichting Eurotransplant International Foundation. In Annual report 2008, edited by A. Oosterlee and A. Rahmel, 14-25. Leiden: Eurotransplant International Foundation. http:// www.eurotransplant.org/cms/mediaobject.php?file=ar 2008.pdf.

Farrell, A.-M., D. Price, and M. Quigley, eds. 2011. Organ shortage: Ethics, law and pragmatism. Cambridge: Cambridge University Press.

Federal Evaluation Cell on Palliative Care. 2008. Evaluation report palliative care [in Dutch]. Brussels: Federal Government Department Public Health, Food Safety and Environment, DG Organisation Health Care Services, Cell Chronic, Elderly and Palliative Care. http://mailsystem. palliatief.be/accounts/15/attachments/rapporten/fed evaluatiecel_mai_2008_rapport_2008_nl.pdf.

Federatie Palliatieve Zorg Vlaanderen. 2003. Dealing with euthanasia and other forms of medically assisted dying [in Dutch]. www.palliatief.be/accounts/143/attachments/ Publicaties/euthanasie_-_standpunt_federatie.doc. Accessed June 4, 2014.

Federatie Palliatieve Zorg Vlaanderen. 2007. End-of-life care: No twin-track policy. http://www.palliatief.be/accounts/143/ attachments/Publicaties/endoflifecare_notwintrackpolicy. pdf. Accessed June 4, 2014.

Federatie Palliative Zorg Vlaanderen. 2012. Palliatieve sedatie. http://www.pallialine.be/template.asp?f=rl_palliatieve_ sedatie.htm. Accessed July 14, 2014.

Federatie Palliatieve Zorg Vlaanderen. 2013. On palliative care and euthanasia. http://www.palliatief.be/accounts/143/ attachments/Publicaties/visietekst_onpalliativecare_and euthanasia_27_05_2013_def.pdf. Accessed June 4, 2014.

Gamester, N., and B. Van den Eynden. 2009. The relationship between palliative care (PC) and legalized euthanasia in Belgium. Journal of Palliative Medicine 12(7): 589-591.

Gilsenan, A., director. 2012. A time to die? Dublin: Yellow Asylum Films.

Gómez, M.P., E. Arredondo, G. Páez, and M. Manyalich. 2012. International registry in organ donation and transplantation 2010. Transplantation Proceedings 44(6): 1592-1597.

Gómez-Batiste, X., C. Caja, J. Espinosa, et al. 2012. The Catalonia World Health Organization demonstration project for palliative care implementation: Quantitative and qualitative results at 20 years. Journal of Pain and Symptom Management 43(4): 783-794. 
Gordts, E. 2013. Nathan Verhelst chooses euthanasia after failed gender reassignment surgeries. The Huffington Post, October 5. http://www.huffingtonpost.com/2013/10/05/nathanverhelst-euthanasia-belgium_n_4046106.html.

Griffiths, J., H. Weyers, and M. Adams. 2008. Euthanasia and law in Europe. Oxford and Portland: Hart.

Groenewoudn, J.H., A. van der Heide , B.D. OnwuteakaPhilipsen, D.L. Willems, P.J. van der Maas, and G. van der Wal. 2000. Clinical problems with the performance of euthanasia and physician-assisted suicide in The Netherlands. The New England Journal of Medicine 342(8): 551-556.

Hains, C.A.M., and N.J. Hulbert-Williams. 2013. Attitudes toward euthanasia and physician-assisted suicide: A study of the multivariate effects of healthcare training, patient characteristics, religion and locus of control. Journal of Medical Ethics 39(11): 713-716.

Halman, L.C.J.M.. 1999. European values study 1999/2000, EVS '99/2000 (ZA Study 3811) [computer file]. Amsterdam: Steinmetz-archief (P1460).

Hevesi, D. 2008. Hugo Claus, one of Belgium's most renowned authors, dies at 78. The New York Times, March 25. http:// www.nytimes.com/2008/03/25/books/25claus.html?fta=y\&_r=0.

Heylighen, F., and J.L. Bernheim. 2000a. Global Progress I: Empirical evidence for ongoing increases in quality of life. Journal of Happiness Studies 1(3): 323-349.

Heylighen, F., and J.L. Bernheim. 2000b. Global Progress II: Evolutionary mechanisms and their side-effects. Journal of Happiness Studies 1(3): 351-374.

Heymans, A. 2006. L'Universalisme ou la philosophie de l'espoir. Brussels: Le Roseau.

Hösle, V. 1997. Moral und politik. Munich: C.H. Beck.

Hunt, R. 1994. Palliative care: The rhetoric-reality gap. In Willing to listen, wanting to die, edited by H. Kuhse, 115-137. Melbourne: Penguin.

Hurst, S.A., and A. Mauron. 2006. The ethics of palliative care and euthanasia: Exploring common values. Palliative Medicine 20(2): 107-112.

International Federation of Gynecology and Obstetrics (FIGO). 2008. Ethical issues in obstetrics and gynecology. London: FIGO. http://www.figo.org/files/figo-corp/Ethical\% 20Issues $\% 20-\% 20$ English.pdf.

Jansen-van der Weide, M.C., B.D. Onwuteaka-Philipsen, and G. van der Wal. 2005. Granted, undecided, withdrawn, and refused requests for euthanasia and physician-assisted suicide. Archives of Internal Medicine 165(15): 1698-1704.

Janssens, L. 1957. Personalisme en democratisering. Brussel: Arbeiderspers.

Jaspers, B., H.C. Müller-Busch, and F. Nauck. 2009. Integral palliative care - a contradiction in terms? [in German]. Zeitschrift für Palliativmedizin 10(3): 162-126.

Johnstone, M.J. 2012. Organization position statements and the stance of "studied neutrality" on euthanasia in palliative care. Journal of Pain and Symptom Management 44(6): 896-907.

Kettler, D., and F. Nauck. 2010. Palliative care and involvement of anaesthesiology: Current discussions. Current Opinion in Anaesthesiology 23(2): 173-176.

Kimsma, G.K. 2010. Death by request in The Netherlands: Facts, the legal context and effects on physicians, patients and families. Medicine Health Care and Philosophy 13(4): 355-361.

Kouwenhoven, P.S., G.J. van Thiel, N.J. Raijmakers, J.A. Rietjens, A. van der Heide, and J.J. van Delden. 2014. Euthanasia or physician-assisted suicide? A survey from the Netherlands. The European Journal of General Practice 20(1): 25-31.

Kuhse, H., P. Singer, P. Baume, M. Clark, and M. Rickard. 1997. End-of-life decisions in Australian medical practice. Medical Journal of Australia 166(4): 191-196.

Ladrière, J. 2004. La foi chrétienne et le destin de la raison. Brussels: Editions du Cerf.

Lanssens, M., director. 2011. Epilogue. Ghent: Serendipity Films.

Leestmans, D., director. 2013. Euthanasia in prison. Brussels: Canvas. http://www.canvas.be/programmas/panorama/ 56555ea1-3a0c-45e8-ad9d-9cf0583031d2.

Leget, C. 2013. Assisted dying - the current debate in the Netherlands. European Journal of Palliative Care 20(4): 168-171.

Lenaers, R. 2001. Nebuchadnezzar's dream or the end of a medieval Catholic Church. Piscataway, NJ: Gorgias Press.

Lewis, P., and I. Black. 2013. Adherence to the request criterion in jurisdictions where assisted dying is lawful? A review of the criteria and evidence in the Netherlands, Belgium, Oregon, and Switzerland. The Journal of Law, Medicine and Ethics 41(4): 885-898.

Léontine, Z. 1995. What for euthanasia? [in Dutch]. Leuven: Davidsfonds.

Liverani, M., B. Hawkins, and J.O. Parkhurst. 2013. Political and institutional influences on the use of evidence in public health policy: A systematic review. PLoS One 8(10): e77404. doi: 10.1371/journal.pone.0077404.

López-Saca, J.M., J.L. Guzmán, and C. Centeno. 2013. A systematic review of the influence of opioids on advanced cancer patient survival. Current Opinion in Supportive and Palliative Care 7(4): 424-430.

Materstvedt, L.J. 2009. Inappropriate conclusions in research on assisted dying. Journal of Medical Ethics 35(4): 272.

Materstvedt, L.J. 2013. Palliative care ethics: The problems of combining palliation and assisted dying. Progress in Palliative Care 21(3): 158-164. doi:10.1179/1743291X12Y.0000000040.

Materstvedt, L.J., D. Clark, J. Ellershaw, et al. 2003. Euthanasia and physician-assisted suicide: A view from an EAPC Ethics Task Force. Palliative Medicine 17(2): 97-101.

McIntyre, A, 2011. Doctrine of double effect. The Stanford encyclopedia of philosophy, edited by E.N. Zalta. http://plato. stanford.edu/archives/fall2011/entries/double-effect/.

Meeussen, K., L. Van den Block, N. Bossuyt, M. Echteld, J. Bilsen, and L. Deliens. 2010. Physician reports of medication use with explicit intention of hastening the end of life in the absence of explicit patient request in general practice in Belgium. BMC Public Health 10: 186. doi:10.1186/14712458-10-186.

Miccinesi, G., S. Fischer, E. Paci, et al. 2005. Physicians' attitudes towards end-of-life decisions: A comparison between seven countries. Social Science and Medicine 60(9): 1961-1974.

Mitchell, K., and R.G. Owens. 2003. National survey of medical decisions at end of life made by New Zealand general practitioners. British Medical Journal 327: 202. doi:10.1136/bmj. 327.7408.202.

Moniteur Belge. 2014. Loi modifiant la loi du 28 mai 2002 relative à l'euthanasie, en vue d'étendre l'euthanasie aux mineurs. http://www.ieb-eib.org/en/pdf/20140228-loi-euthanasiemineurs.pdf. Accessed May 1, 2013.

Mounier, E. 1949. Le personnalisme: Que sais-je? 7th ed. Paris: Les Presses universitaires de France. 
Nussbaum, M.C. 2008. Liberty of conscience: In defense of America's tradition of religious equality. New York: Basic Books.

Oregon Public Health Division. 2013. Oregon's Death with Dignity Act-2012. http://public.health.oregon.gov/ ProviderPartnerResources/EvaluationResearch/ DeathwithDignityAct/Documents/year15.pdf. Accessed May 1, 2013.

Pardon, K., R. Deschepper, R. Vander Stichele, J. Bernheim, F. Mortier, and L. Deliens. 2009. Preferences of advanced lung cancer patients for patient-centred information and decision-making: A prospective multicentre study in 13 hospitals in Belgium. Patient Education and Counseling 77(3): 421-429.

Pardon, K., R. Deschepper, R. Vander Stichele, et al. 2012a. Preferred and actual involvement of advanced lung cancer patients and their families in end-of-life decision making: A multicenter study in 13 hospitals in Flanders, Belgium. Journal of Pain and Symptom Management 43(3): 515526.

Pardon, K., R. Deschepper, R. Vander Stichele,et al. 2012b. Expressed wishes and incidence of euthanasia in advanced lung cancer patients. European Respiratory Journal 40(4): 949-956.

Pasman, H.R.W., M.L. Rurup, D.L. Willems, and B.D. Onwuteaka-Philipsen. 2009. Concept of unbearable suffering in context of ungranted requests for euthanasia: Qualitative interviews with patients and physicians. British Medical Journal 339(7732): 1235-1237. doi:10.1136/bmj.b4362.

Pasman, H.R., D.L. Willems, and B.D. Onwuteaka-Philipsen. 2013. What happens after a request for euthanasia is refused? Qualitative interviews with patients, relatives and physicians. Patient Education and Counseling 92(3): 313-318.

Pereira, J. 2011. Legalizing euthanasia or assisted suicide: The illusion of safeguards and controls. Current Oncology 18(2): e38-e45.

Pereira, J., D. Anwar, G. Pralong, J. Pralong, C. Mazzocato, and J.M. Bigler. 2008. Assisted suicide and euthanasia should not be practiced in palliative care units. Journal of Palliative Medicine 11(8): 1074-1076.

Perrez, J., and M. Reuchamps, eds. 2012. Les relations communautaires en Belgique: Approches politiques et linguistiques. Louvain-La-Neuve: Academia-l'Harmattan.

Pousset, G., J. Bilsen, J. Cohen, K. Chambaere, L. Deliens, and F. Mortier. 2010. Medical end-of-life decisions in children in Flanders, Belgium: A population-based postmortem survey. Archives of Pediatric and Adolescent Medicine 164(6): 547553.

Provoost, V., F. Cools, F. Mortier, et al. 2005. Medical end-of-life decisions in neonates and infants in Flanders. The Lancet 365(9467): 1315-1320.

Quill, T.E., and A.P. Abernethy. 2013. Generalist plus specialist palliative care - creating a more sustainable model. The New England Journal of Medicine 368(13): 1173-1175.

Raadgevend Comité voor Bio-ethiek. 1997. Advies nr. 1 dd.12 mei 1997 betreffende de wenselijkheid van een legale regeling van euthanasie. http://www.health.belgium.be/ eportal/Healthcare/Consultativebodies/Commitees/ Bioethics/Opinions/index.htm. Accessed May 1, 2013.

Ramsay, J.H.R. 1994. A king, a doctor, and a convenient death. British Medical Journal 308(6941): 1445. doi:10.1136/bmj. 308.6941.1445.
Randall, F. 2013. Commentary on "Assisted dying - the current situation in Flanders: Euthanasia embedded in palliative care." European Journal of Palliative Care 20(6): 274-276.

Rawls, J. 1992. A theory of justice. Oxford: Oxford University Press.

Roeland, E., J. Cain, C. Onderdonk, K. Kerr, W. Mitchell, and K. Thornberry. 2014. When open-ended questions don't work: The role of palliative paternalism in difficult medical decisions. Journal of Palliative Medicine 17(4): 415-420.

Rurup, M.L., H.M. Buiting, H.R. Pasman, P.J. van der Maas, A. van der Heide, and B.D. Onwuteaka-Philipsen. 2008. The reporting rate of euthanasia and physician-assisted suicide: A study of the trends. Medical Care 46(12): 1198-1202.

Saunders, C. 1976. Care of the dying-1: The problem of euthanasia. Nursing Times 72(26): 1003-1005.

Schillebeeckx, E. 1982. Gerechtigheid en liefde: Genade en bevrijding [Justice and love: Grace and liberation]. Nelissen: Bloemendaal.

Seale, C. 2009. End-of-life decisions in the UK involving medical practitioners. Palliative Medicine 23(3): 198-204.

Seale, C. 2010. The role of doctors' religious faith and ethnicity in taking ethically controversial decisions during end-of-life care. Journal of Medical Ethics 36(11): 677-682.

Siebold, S. 2013. Belgium twin brothers die by euthanasiaassisted suicide should be legal in America. The Huffington Post, January 16. http://www.huffingtonpost.com/stevesiebold/belgium-twins-euthanasia-_b 2481227.html.

Smets, T., J. Bilsen, J. Cohen, M.L. Rurup, F. Mortier, and L. Deliens. 2010. Reporting of euthanasia in medical practice in Flanders, Belgium: Cross sectional analysis of reported and unreported cases. British Medical Journal 341: c5174. doi: 10.1136/bmj.c5174.

Smets, T., J. Cohen, J. Bilsen, Y. Van Wesemael, M.L. Rurup, and L. Deliens. 2012. The labelling and reporting of euthanasia by Belgian physicians: A study of hypothetical cases. European Journal of Public Health 22(1): 19-26.

Sterckx, S., K. Raus, and F. Mortier, eds. 2013. Continuous sedation at the end of life: Ethical, clinical and legal perspectives. Cambridge: Cambridge University Press.

Swarte, N.B., M.L. van der Lee, J.G. van der Bom, J. van den Bout, and A.P. Heintz. 2003. Effects of euthanasia on the bereaved family and friends: A cross sectional study. British Medical Journal 327(7408): 189. doi:10.1136/bmj.327. 7408.189.

Szmukler, G. 2014. When psychiatric diagnosis becomes an overworked tool. Journal of Medical Ethics 40: 517-520.

Tariman, J.D., D.L. Berry, B. Cochrane, A. Doorenbos, and K. Schepp. 2010. Preferred and actual participation roles during health care decision making in persons with cancer: A systematic review. Annals of Oncology 21(6): 1145-1151.

Temel, J.S., J.A. Greer, A. Muzikansky, et al. 2010. Early palliative care for patients with metastatic non-small-cell lung cancer. The New England Journal of Medicine 363(8): 733-742

Theuns, P., J. Hofmans, and J.L. Bernheim. 2014. Anamnestic comparative self-assessment (ACSA). In Encyclopedia of quality of life and well-being research, edited by A.C. Michalos, 166-169. Heidelberg and New York: Springer.

Van de Velde, Q., director. 2012. Vivre avec l'Euthanasie. http:// www.clav.be/prod_euthanasie.html. Accessed June 4, 2014. 
Vanden Berghe, P., A. Mullie, M. Desmet, and G. Huysmans. 2013. Assisted dying - the current situation in Flanders: Euthanasia embedded in palliative care. European Journal of Palliative Care 20(6): 266-272.

Van den Block, L., R. Deschepper, J. Bilsen, N. Bossuyt, V. Van Casteren, and L. Deliens. 2009. Euthanasia and other end of life decisions and care provided in final three months of life: Nationwide retrospective study in Belgium. British Medical Journal 339: b2772. doi:10.1136/bmj.b2772.

Van den Enden, H. 1995. To make our end of life humane [in Dutch]. Brussels: VUB Press.

van der Burg, W. 1991. The slippery slope argument. Ethics 102(1): 42-65.

van der Heide, A., L. Deliens, K. Faisst, et al. 2003. End-of-life decision-making in six European countries: Descriptive study. The Lancet 362(9381): 345-350.

van der Heide, A., B.D. Onwuteaka-Philipsen, M.L. Rurup, et al. 2007. End-of-life practices in the Netherlands under the Euthanasia Act. The New England Journal of Medicine 356(19): 1957-1965

Van Raemdonck, D., G.M. Verleden, L. Dupont, et al. 2011. Initial experience with transplantation of lungs recovered from donors after euthanasia. Applied Cardiopulmonary Pathophysiology 15: 38-48.

Van Wesemael, Y., J. Cohen, B.D. Onwuteaka-Philipsen, J. Bilsen, and L. Deliens. 2009a. Establishing specialized health services for professional consultation in euthanasia: Experiences in the Netherlands and Belgium. BMC Health Services Research 9: 220. doi:10.1186/ 1472-6963-9-220.
Van Wesemael, Y., J. Cohen, B.D. Onwuteaka-Philipsen, J. Bilsen, W. Distelmans, and L. Deliens. 2009b. Role and involvement of life end information forum physicians in euthanasia and other end-of-life care decisions in Flanders, Belgium. Health Services Research 44(6): 2180-2192.

Van Wesemael, Y., J. Cohen, J. Bilsen, T. Smets, B. OnwuteakaPhilipsen, and L. Deliens. 2011. Process and outcomes of euthanasia requests under the Belgian act on euthanasia: A nationwide survey. Journal of Pain and Symptom Management 42(5): 721-733.

Van Wesemael, Y., J. Cohen, J. Bilsen, et al. 2012. Implementation of a service for physicians' consultation and information in euthanasia requests in Belgium. Health Policy 104(3): 272-278.

Vanhecke, N. 2013. Euthanasiezaak geïnterneerde verkrachter uitgesteld. De Standaard, October 17. http://www.standaard.be/ cnt/dmf20131017_006.

Vermeersch, E., and̄ J. Braeckman. 2008. De rivier van Herakleitos: Een eigenzinnige visie op de wijsbegeerte. Antwerp: Houtekiet.

Wheeler, R. 2006. Gillick or Fraser? A plea for consistency over competence in children. British Medical Journal 332(7545): 807. doi:10.1136/bmj.332.7545.807.

World Health Organization [WHO]. 2014. Definition of palliative care. http://www.who.int/cancer/palliative/definition/en/. Accessed June 1, 2014.

Woods, S. 2007. Death's dominion: Ethics at the end of life. New York: McGraw Hill Open University Press.

Ysebaert, D., G. Van Beeumen, K. De Greef, et al. 2009. Organ procurement after euthanasia: Belgian experience. Transplantation Proceedings 41(2): 585-586. 